\title{
Pengembangan Sistem Informasi Manajemen Supplier dan Barang dengan Extreme Programming
}

\author{
http://dx.doi.org/10.28932/jutisi.v6i1.2132
}

\author{
Astria Hijriani ${ }^{\# 1}$, Jannati Asri Safitri ${ }^{\bowtie \# 2}$, Rd Irwan Adi Pribadi ${ }^{\# 3}$, Rico Andrian ${ }^{\# 4}$ \\ ${ }^{\#} J u r u s a n$ Ilmu Komputer, Universitas Lampung \\ Jl. Prof. Sumantri Brojonegoro No.1, Gedong Meneng, Bandar Lampung \\ ${ }^{1}$ astria.hijrianiefmipa.unila.ac.id \\ 2jannati30fitri@gmail.com \\ 3irwan.adipribadiefmipa.unila.ac.id \\ ${ }^{4}$ rico.andrianefmipa.unila.ac.id
}

\begin{abstract}
The case study was taken from one of trading companies in Lampung. The company sells Muslim fashion products from a large number of suppliers. Suppliers data is recorded in detail manually, as well as products recorded. Manual data collection can result in recording errors, data easily tucked, or not recorded. This research develops an information system to help the company in data collection of suppliers and products automatically based on web using Laravel as a framework. This system is built using extreme programming methods and has features that focus on collecting suppliers, products, and product shipments. The results of system testing using the black box testing method shows that the system has fulfilled functional requirements and user needs.
\end{abstract}

Keywords- Management Information System; Product; Supplier.

\section{Pendahuluan}

Produk merupakan segala sesuatu yang dapat ditawarkan ke pasar atau konsumen untuk mendapatkan perhatian, dibeli, digunakan, atau di konsumsi yang dapat memuaskan keinginan atau kebutuhan [1]. Pakaian merupakan suatu produk yang dibutuhkan oleh setiap individu. Berbagai jenis pakaian tersedia dalam berbagai pilihan mulai dari bahan, model, warna, dan lain-lain. Studi kasus penelitian ini diambil dari salah satu perusahaan yang ada di Lampung. Perusahaan tersebut menjual pakaian muslim dengan berbagai pilihan busana yang dibutuhkan oleh konsumen mulai dari pakaian muslim dewasa hingga anak-anak.

Pakaian tersebut disuplai oleh supplier. Perusahaan tersebut memiliki kurang lebih seratus supplier. Supplier yang terdaftar di perusahaan akan didata secara manual. Supplier akan mengirimkan barang saat owner menghubungi untuk melakukan pembelian barang. Barang yang dikirim oleh supplier dan telah sampai di perusahaan akan dilakukan pencatatan transaksi pembelian barang dari faktur. Pencatatan transaksi pembelian barang dari supplier nantinya dimaksudkan sebagai modul pembelian pada sistem ini. Barang yang telah sampai juga dilakukan pemeriksaan untuk mengetahui kesesuaian barang apakah terjadi kerusakan atau perbedaan jumlah barang yang diminta. Jika terdapat barang yang rusak, maka akan dilakukan return barang. Barang yang sudah selesai diperiksa dan tidak ada masalah akan didata secara manual ke dalam Microsoft Excel.

Pendataan supplier dan barang yang dilakukan secara manual akan menyebabkan terjadinya kesalahan pendataan, data terselip, bahkan terdapat data supplier atau barang tidak tercatat di Microsoft Excel. Pendataan secara manual juga membutuhkan waktu yang lama dan kurang efisien.

Masalah lainnya yaitu terjadi dalam hal pengiriman barang, proses bisnis yang terjadi dalam hal pengiriman barang di perusahaan yaitu, barang akan dikirim ketika owner menghubungi supplier untuk melakukan pembelian barang kembali (restock). Pengiriman barang yang dikirim oleh supplier membutuhkan waktu beberapa hari dari pengemasan hingga barang sampai di perusahaan. Pengiriman yang membutuhkan waktu beberapa hari akan mengakibatkan kekosongan stok barang di gudang.

Beberapa supplier di perusahaan bahkan ada yang berinisiatif mengirimkan barang ke perusahaan sebelum dihubungi oleh owner. Supplier tersebut berpikir, barang yang mereka kirimkan sebelumnya sudah habis di perusahaan tersebut. Karena hal tersebut timbul masalah terjadi penumpukan stok ketika barang yang dikirim masih banyak dan ditambah lagi dengan barang baru, padahal barang tersebut kurang diminati oleh pembeli.

Supplier dan pihak perusahaan harus memiliki hubungan relasi yang baik dalam berbisnis agar kedua belah pihak sama-sama diuntungkan sehingga tidak terjadi kesalahpahaman dalam berkomunikasi seperti halnya 
masalah pengiriman barang secara inisiatif oleh supplier. Hubungan antara Supplier dan perusahaan ini dikenal dengan Supplier Relationship Management (SRM). Supplier Relationship Management adalah pendekatan secara komprehensif untuk mengelola interaksi, komunikasi, dan bagaimana bekerja lebih efektif dengan Supplier agar samasama saling menguntungkan. Supplier dan perusahaan harus bersama-sama mencapai tujuan mereka [2].

Penelitian yang membahas tentang SRM salah satunya yaitu "Analisis Pengaruh Top Manajement Commitment terhadap Supplier Performance dan Supplier Relationship Manajemen pada Hotel Budget di Surabaya". Penelitian tersebut membahas pentingnya Supplier Relationship Manajemen yang berdampak pada peningkatan kinerja perusahaan. Pada penelitian tersebut dijelaskan bagaimana terciptanya hubungan yang baik antara perusaahan dan supplier mereka. Dengan terciptanya hubungan tersebut, maka memberikan kemudahan dalam proses kerja yang dilakukan perusahaan. Salah satunya adalah dengan mengurangi resiko kesalahan dalam melakukan pesanan barang ke supplier, kesalahan pengiriman oleh pihak supplier, dapat menurunkan biaya transaksi atau mungkin dapat dihilangkan karena adanya hubungan yang baik di kedua belah pihak. Analisis tersebut menyebutkan sangat penting untuk menggandeng supplier yang mampu mengerti visi dan misi perusahaan sehingga dapat menyelaraskannya dalam rangka mengembangkan bisnis hingga masa mendatang [3].

Berdasarkan latar belakang tersebut, yang menjadi tujuan penelitian ini yaitu membuat sistem informasi yang pendataan supplier dan barang menggunakan framework Laravel. Tujuan lainnya yaitu membuat sistem informasi yang dapat memberikan notifikasi kepada supplier ketika stok barang mereka hampir habis. Notifikasi tersebut dibuat agar tidak ada lagi supplier yang berinisiatif mengirimkan barang secara random sehingga dapat mengurangi miss comunication antara supplier dan perusahaan serta tercipta hubungan supplier relationship management yang baik antara perusahaan dan supplier.

Pada pelaksanaannya penelitian ini tergabung dalam satu tim yang beranggotakan empat orang. Penelitian tersebut memiliki empat pembagian modul berbeda yakni pembelian, penjualan, dashboard, dan akuntansi. Jadi, pada penelitian ini, yang di fokuskan adalah modul pembeliannya saja yang mencakup pendataan supplier, pembelian, dan pendataan barang. Sedangkan untuk modul lainnya akan diimplementasikan oleh anggota tim yang lain sesuai dalam pembagian modulnya.

Pengimplementasian sistem ini akan bermanfaat untuk perusahaan karena dapat meminimalisir kesalahan dalam menginputkan data dan juga data terselip, membantu pegawai dalam mengefisiensikan waktu kerja, dan membuat owner dapat mengontrol serta mengawasi persediaan barang yang ada di perusahaan. Manfaat lainnya yaitu supplier akan dapat melihat jumlah barang mereka yang hampir habis lewat notifikasi.

Batasan masalah pada penelitian yaitu hanya membuat atau berfokus pada modul pembelian barang. Nantinya sistem informasi ini dapat melakukan pendataan supplier, barang, dan juga transaksi pembelian. Penelitian ini akan berbasis web dan menggunakan framework Laravel. Sistem informasi ini merupakan sistem yang berkaitan dengan tiga modul lainnya yaitu modul penjualan (sistem customer relationship management), modul dashboard (sistem business intelligence dashboard), dan modul akuntansi (sistem informasi akuntansi). Sistem informasi ini akan berfokus pada pendataan supplier, pendataan barang, dan pendataan transaksi. Sistem ini juga akan berkaitan dengan hubungan supplier dan pihak perusahaan melalui pendekatan SRM.

\section{TINJAUAN PUSTAKA}

\section{A. Penelitian Terdahulu}

Pada jurnal yang berjudul "Sistem Informasi Inventori Gudang Untuk Mengontrol Persediaan Barang Pada Gudang Studi Kasus: PT Alaisys Sidoarjo". Penelitian tersebut menjelaskan pendataan gudang yang masih manual seperti pencatatan informasi penjualan dan persediaan barang menggunakan bon nota buku pencatatan dan laporan yang masih ditulis tangan. Untuk mendapatkan data yang dibutuhkan harus mencari satu persatu nota yang telah disimpan. Penelitian tersebut menghasilkan sebuah sistem inventori gudang berbasis web yang dapat mendata barang, transaksi, dan laporan barang. Sistem ini membantu perusahaan dalam mengawasi dan mengontrol barang sehingga dapat meningkatkan efektivitas perusahaan. Sistem ini juga memudahkan karyawan dalam melakukan bagian pengontrolan persediaan barang [4]. Keterkaitan penelitian ini dengan penelitian yang akan dilakukan adalah bagaimana membuat sistem informasi yang dapat mendata barang dan transaksi secara otomatis.

Penelitian lainnya yaitu berjudul "Perancangan Sistem Stok Barang di Warehouse Berbasis Web". Penelitian ini mengambil studi kasus pada PT. Mulia Andalan Gemilang. Pendataan stok barang masih dengan cara manual atau masih mencatat kedalam buku. Pencatatan meliputi data barang masuk dari supplier dan data barang keluar sebagai barang terjual kepada customer. Dengan proses pencatatan data yang tradisional itu perusahaan mengalami banyak kerugian, yaitu kesalahan dalam perhitungan stok barang secara manual dan pembuatan laporan juga terlambat. Penelitian tersebut menghasilkan sistem berbasis web yang menerapkan teknologi komputer secara keseluruhan dalam pencatatan stok gudang agar meningkatkan kinerja operasi perusahaan. Manfaat sistem ini yaitu dapat menghemat waktu pemrosesan data dan lebih cepat dalam pembuatan laporan stok barang masuk dan keluar [5]. Keterkaitan antara penelitian ini dengan penelitian yang dilakukan adalah bagaimana membuat sistem yang dapat mendata stok barang secara otomatis agar lebih efektif dan efisien. 
Penelitian selanjutnya berjudul "Perancangan dan Implementasi Sistem Informasi Persediaan Bahan Baku dan Suku Cadang di PT. Triteguh Manunggal Sejati Banjarbaru". Dalam penelitian ini pengelolaan persediaan barang masih dilakukan secara manual dan belum terkomputerisasi. Perusahaan itu masih menggunakan media kertas sehingga pencarian data dilakukan dengan cara menelusuri buku besar yang sangat menyita waktu. Setiap entitas belum terintegrasi yang menyebabkan keterlambatan kinerja dan kurang akuratnya informasi. Masalah lain yaitu belum adanya aplikasi untuk mengingatkan apabila ada stok barang yang sudah mencapai titik pesan kembali (reorder point), yang harus segera dipesan untuk menghindari kehabisan stok. Analisis kebutuhan sistem yang dilakukan menghasilkan kebutuhan fungsional yaitu sistem harus dapat melakukan pendataan barang, pendataan karyawan, pendataan supplier, dan pencetakan laporan. Keterkaitan penelitian ini dengan penelitian yang akan dilakukan adalah membuat sistem yang dapat melakukan pendataan secara otomatis untuk pendataan barang, pendataan supplier, dan pemberitahuan saat stok barang hampir habis [6].

\section{B. Supplier}

Menurut Bunafit Nugroho dalam bukunya, supplier adalah pihak yang menjadi penyedia barang yang dijual pada perusahaan/ toko, bisa disebut juga dengan distributor atau agen yang mendatangkan barang dagangan ke sebuah perusahaan/ toko. Perusahaan/ toko itu sendiri juga dapat bertindak sebagai supplier, misalnya saja ada sebagian produk yang dijual adalah produk rumahan buatan dari perusahaan itu sendiri [7].

\section{Supplier Relationship Management (SRM)}

Supplier relationship management (SRM) adalah istilah umum tentang memutuskan level intervensi, tingkat, dan hubungan dasar yang dibutuhkan dengan pemasok (Supplier). Sumber daya yang diarahkan sebagian besar hanya untuk bekerja dengan para pemasok, namun tidak menyadari nilai yang signifikan dan berharga yang akan kita dapatkan dari pemasok [8].

Supplier Relationship Management adalah salah satu pendekatan untuk menghubungkan rantai pasokan dan pemasok dengan kepentingan strategis organisasi untuk berhasil mengidentifikasi dan mendorong peluang bisnis yang belum tersentuh. Pendekatan SRM memberikan kerangka kerja yang jelas untuk mengelola hubungan di semua tingkat, fungsi yang berbeda, mengurangi tingkat kerumitan, dan meningkatkan transparansi di kedua sisi [9].

SRM yaitu pendekatan sistematis untuk mengembangkan dan mengelola kemitraan. Keberhasilan SRM juga sangat bergantung pada kompetensi pemasok (supplier). Kompetensi pemasok (supplier) adalah sumber daya, proses dan ukuran pemasok yang ditawarkan kepada perusahaan pembeli. Supplier relationship management sering dianggap sebagai proses operasional/taktis yang akan menyelesaikan masalah dan mengurangi biaya [10].

\section{Pendataan}

Pendataan adalah proses pembuktian yang ditemukan dari hasil penelitian yang dapat dijadikan dasar kajian atau pendapat. Secara teknis pengertian pendataan adalah proses yang lebih berkaitan dengan pengumpulan datanya secara empiris. Menurut penulis pendataan dapat diartikan sebagai proses pembuktian dari hasil penelitian dan lebih dikaitkan dengan pengumpulan secara empiris [11].

\section{E. Extreme Programming}

Extreme Programming (XP) adalah model yang banyak digunakan untuk mengembangkan perangkat lunak dengan kualitas tinggi dalam metode pengembangan Agile. Extreme Programming (XP) berfokus pada peningkatan kualitas perangkat lunak dan juga berfokus pada respons terhadap perubahan kebutuhan [12].

Pada metode Agile, sistem dibangun dengan desain yang sederhana, pengujian dilakukan pada tahap pengembangan, dan dokumentasi perangkat lunak yang cukup. Extreme programming (XP) cocok untuk individu, tim kecil, dan juga tim menengah. Extreme programming dalam pelaksanaannya mengutamakan komunikasi yang baik antar anggota tim. Pengerjaan menggunakan metode ini dilakukan secara incremental dan interaktif untuk menghadapi kebutuhan yang berubah dengan cepat [13].

Metode Extreme Programming sering juga dikenal dengan metode XP. Metode ini dicetuskan oleh seorang pakar software engineering yaitu Kent Beck. XP adalah suatu model pengembangan perangkat lunak yang menyederhanakan berbagai tahapan pengembangan menjadi lebih efisien, adaptif dan fleksibel [14].

Nilai dasar metode extreme programming yaitu:

1. Communication: memfokuskan komunikasi antara programmer dengan user.

2. Courage: pengembang harus memiliki keyakinan, keberanian dan integritas dalam melakukan tugasnya.

3. Simplicity: lakukan semua dengan sederhana.

4. Feedback: mengandalkan feedback.

5. Quality work: proses berkualitas berimplikasi pada perangkat lunak yang berkualitas sebagai hasil akhirnya.

\section{METODOLOGI}

\section{F. Metode Pengumpulan Data}

1. Wawancara

Wawancara merupakan salah satu metode pengumpulan data yang digunakan untuk memperoleh informasi dari narasumber. Wawancara dilakukan dengan berinteraksi atau memberikan pertanyaan kepada narasumber terkait dengan informasi yang dibutuhkan dalam melakukan penelitian. Pengembang telah melakukan wawancara sebanyak 4 kali dengan owner 
perusahaan. Wawancara pertama mengenai sejarah, wawancara kedua mengenai masalah yang terjadi, wawancara ketiga tentang apa yang dibutuhkan, dan wawancara keempat melakukan validasi apa yang dibutuhkan oleh pihak perusahaan.

2. Observasi

Observasi merupakan salah satu teknik pengumpulan data. Pengembang melakukan pengamatan secara langsung ke objek penelitian untuk melihat dari dekat kegiatan apa saja yang dilakukan dan mendapatkan informasi yang akan dibutuhkan untuk melancarkan penelitian tersebut. Pengembang telah melakukan observasi sebanyak 3 kali. Observasi pertama dilakukan untuk mengetahui proses bisnis perusahaan, observasi kedua dan ketiga dilakukan untuk mendapatkan fiturfitur yang akan dibuat ke dalam sistem.

\section{G. Metode Pengembangan Sistem}

Metodologi yang digunakan dalam pembuatan sistem informasi ini yaitu metode extreme programming (XP). Extreme programming memiliki beberapa tahapan dalam pelaksanaannya yaitu planning, desain, coding, dan tahap testing [15]. Tahapan-tahapan yang ada pada metode extreme programming tersebut dapat dilihat pada Gambar 1.

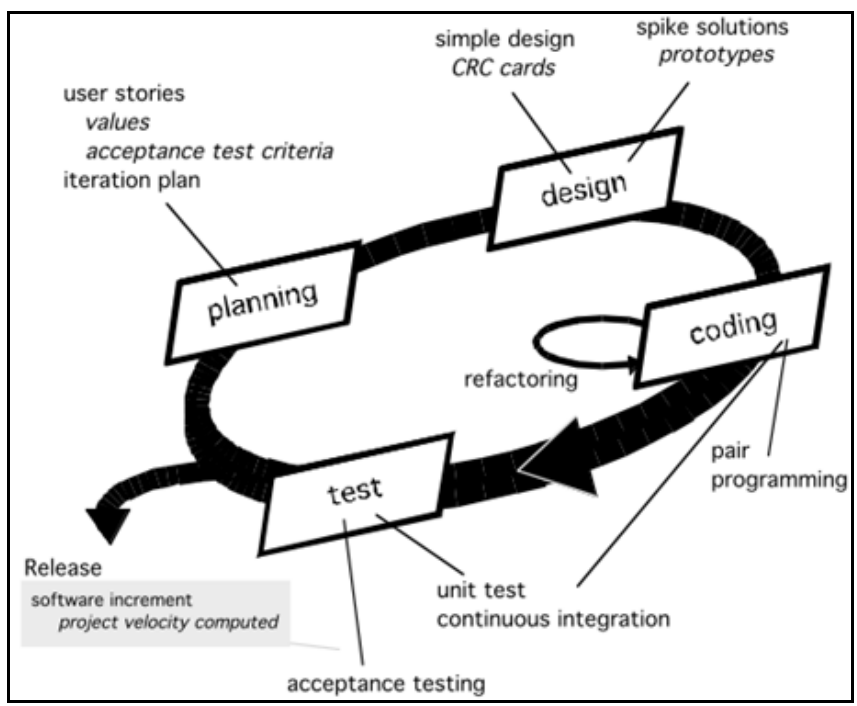

Gambar 1. Metode Extreme Programming (XP) [16]

\section{Planning (Perencanaan)}

Dalam tahap ini akan dimulainya analisis tentang pemahaman konteks sistem informasi yang akan dibuat yang dapat dilihat pada user stories, pengembang mendefinisikan keluaran (output), fitur yang akan di buat, fungsi aplikasi, dan juga menjelaskan alur pengembangan aplikasi.

\section{Design (Perancangan)}

Tahap ini dilakukan membuat desain sistem informasi manajemen untuk pendataan supplier dan barang secara sederhana. Salah satu cara untuk mendesain aplikasi biasanya digunakan pemetaan untuk membangun kelas-kelas yang akan digunakan seperti use case diagram, class diagram, atau diagram objek.

\section{Coding (Pengkodean)}

Tahap ini dalam pengembangan aplikasi dengan menggunakan metode Extreme programming akan dilakukan proses coding untuk membangun sistem informasi manajemen supplier dan barang.

\section{Testing (Pengujian)}

Tahap ini memfokuskan pada pengujian fitur-fitur yang ada di dalam sistem informasi manajemen supplier dan barang. Sistem akan di uji sehingga tidak ada kesalahan (error) dan aplikasi yang dibuat sesuai dengan kebutuhan pengguna (user).

\section{H. Analisis Kebutuhan Masalah}

Dalam perusahaan tersebut pelaksanaan proses bisnisnya masih dilakukan secara manual sehingga banyak terjadi kesalahan pendataan informasi. Berdasarkan proses bisnis yang terjadi pemilik perusahaan membutuhkan informasi secara akurat dan efisien. Karena hal tersebut pengembang melakukan observasi dan wawancara untuk membuat user stories. User stories merupakan salah satu bagian dari tahap planning pada metode XP. Berikut user stories owner:

a. Sebagai seorang owner, saya ingin adanya pendataan supplier secara sistematis karena di perusahaan saya pendataan supplier masih secara manual.

b. Sebagai seorang owner, saya ingin adanya pendataan barang secara sistematis mulai dari data kategori barang, satuan barang, rak barang, jenis barang, dan pricing barang.

c. Sebagai seorang owner, saya ingin adanya pendataan transaksi pembelian barang dari supplier ke perusahaan dan pendataan return/ pengembalian barang dari perusahaan ke supplier.

d. Sebagai seorang owner, saya ingin supplier mengetahui saat stok barang mereka hanya tersisa sedikit di perusahaan. 
e. Sebagai seorang owner, saya ingin supplier mengetahui daftar barang mereka yang tidak perlu mereka kirimkan ke perusahaan.

\section{Analisis Kebutuhan Sistem}

Setelah melihat user stories yang sudah disampaikan oleh owner, maka akan dibuat sistem informasi manajemen supplier dan barang berbasis web dimana terdiri dari beberapa komponen dalam pengembangannya yaitu menggunakan framework Laravel, CSS dan Bootstrap.

Penerapan sistem pada proses bisnis yang terjadi di perusahaan nantinya akan membuat informasi yang didata secara manual menjadi otomatis sehingga mempermudah dalam menjalankan proses selanjutnya. Sistem ini dapat mendata seluruh data pembelian produk dari supplier, data barang, dan data supplier. Sistem ini akan memudahkan pihak perusahaan dalam pendataan sehingga dapat meminimalisir kesalahan dalam penginputan data informasi barang ataupun supplier.

\section{E. Perancangan Sistem}

Perancangan untuk sistem ini akan diperlihatkan pada diagram use case. Gambar 2 memperlihatkan use case diagram yang menunjukkan bahwa terdapat dua level user yaitu Admin Gudang dan supplier. Admin Gudang dapat mengakses stok gudang, mengelola barang, rak gudang, satuan barang, kategori barang, transaksi pengiriman pembelian barang, return barang, dan mengelola supplier. Supplier akan dapat mengakses barang dimana didalamnya terdapat fitur barang tunda dan mengakses notifikasi.

\section{HASIL DAN PEMBAHASAN}

\section{A. Hasil Penelitian}

Sistem informasi manajemen supplier dan barang adalah sistem yang dibuat untuk memudahkan pemilik perusahaan dalam melakukan pendataan stok barang dan supplier. Sistem ini juga memudahkan supplierl pemasok untuk melihat pergerakan barang mereka lewat pemberitahuan (notification) yang ada di sistem. Sistem informasi manajemen supplier dan barang memiliki dua tingkatan user yaitu petugas gudang yang bertugas sebagai admin dan supplier. Petugas gudang bertugas mengelola Sistem informasi manajemen supplier dan barang.

Petugas gudang memiliki akses untuk mengelola supplier, mengelola barang, mengelola pengiriman barang dari supplier, mengelola return pembelian barang supplier, mengelola kategori, mengelola harga, mengelola stok, mengelola rak di gudang, mengelola satuan, mengelola jenis kode barang, dan mengelola user. Supplier memiliki akses untuk melihat stok barang dan transaksi pengiriman barang mereka yang ada di perusahaan. Supplier juga dapat melihat pemberitahuan yang muncul saat stok barang mereka di perusahaan sudah dalam batas minimal sehingga para supplier dapat mengubungi owner untuk mengonfirmasi

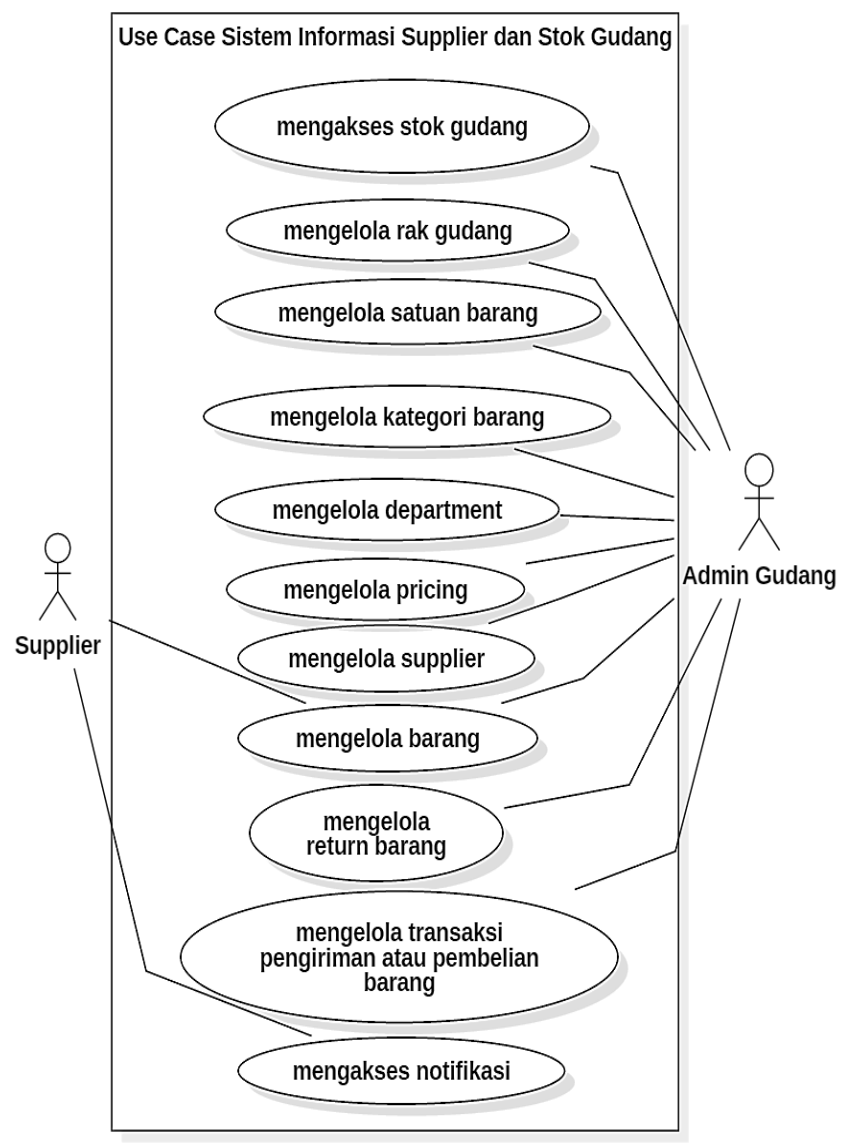

Gambar 2. Use case sistem informasi manajemen supplier dan barang.

akankah dilakukan restock barang atau tidak. Role supplier pada sistem ini ditujukan untuk menciptkan relasi dan komunikasi yang baik antara supplier dan perusahaan. Hubungan yang baik antara supplier dan perusahaan dapat disebut Supplier Relationship Management.

Pengembangan sistem ini menggunakan metodologi Extreme programming. Sistem informasi manajemen supplier dan barang berbasis web, diakses secara online, dan dibangun dengan menggunakan bahasa pemrograman PHP juga Javascript. PHP (Hypertext PreProcessor) digunakan sebagai bahasa pemrograman server side yang berjalan pada sisi server, dan Javascript digunakan sebagai bahasa pemrograman client side yang berjalan pada sisi client atau browser. Sistem informasi manajemen supplier dan barang dalam pengembangannya dibangun dengan menggunakan framework Laravel.

Atom Text Editor versi 1.25.1 untuk menuliskan kode program. Balsamiq Mockup versi 3.5.8 untuk membuat desain interface. XAMPP 7.1.10 sebagai local server dalam pengembangan sistem MYSQL dan PHP. Star UML untuk membuat diagram model sistem. Web Browser Google Chrome untuk menguji dan menjalankan sistem. Laptop Lenovo Z40-75 sebagai alat bantu mengembangkan sistem. 
Windows $10 \quad 64$ bit sebagai sistem operasi untuk menjalankan berbagai aplikasi.

\section{B. Pembahasan}

Pencatatan data supplier dan barang merupakan komponen penting dalam perusahaan. Maka dibuat sistem untuk menangani pendataan supplier dan barang agar proses bisnis yang ada dapat berjalan dengan baik. Sistem informasi manajemen supplier dan barang dikembangkan menggunakan metode extreme programming (XP). XP memiliki tahapan yaitu planning, design, coding, dan testing. User stories yang mana masuk dalam tahap planning dan perancangan sistem yang masuk dalam tahap design telah dijelaskan pada bab 3 metodologi.

Sistem ini juga saling terintegrasi atau terhubung dengan tiga sistem yang berbeda, hal ini juga sempat disinggung pada bab pendahuluan. Ketiga sistem yang berbeda itu antara lain Sistem BID (Business Intelligence Dashboard), Sistem SIA (Sistem Informasi Akuntansi), dan Sistem CRM (Customer Relationship Management). Sistem SDB (Supplier dan Barang) yang memiliki data awal supplier dan barang sistem SDB (Supplier dan Barang) mengirim data ke semua sistem (BID, SIA, dan CRM). Sistem pendataan supplier dan barang mengirim data untuk sistem customer relationship management berupa data supplier, data barang, data kategori barang, dan data jenis kode barang agar pergerakan stok barang di perusahaan tersebut bisa dilakukan secara otomatis juga pendataan penjualan pada sistem CRM lebih sistematis, sistem ini juga mengirimkan data ke sistem business intelligence dashboard berupa data supplier, data kategori, dan data barang untuk diolah kembali menjadi informasi yang dapat membantu owner dalam melihat pergerakan bisnis di perusahaannya.

Sistem supplier dan barang juga mengirimkan data ke sistem akuntansi berupa data pembelian barang atau data transaksi pembelian barang dari supplier yang mencakup total harga pembelian dan data supplier untuk diolah menjadi data yang dibutuhkan dalam hal keuangan perusahaan. Pengiriman data tersebut menggunakan API (Application Programming Interface) yang merupakan seperangkat antarmuka (bisa berbentuk fungsi, method atau URL endpoint) yang bisa digunakan untuk mengembangkan aplikasi, baik dalam satu platform maupun lintas platform. Berikut ini merupakan implementasi tampilan sistem yang berhasil dibuat menggunakan framework Laravel.

Sistem ini memiliki fitur pendataan supplier, barang, dan juga pembelian barang. Penjualan tidak di implementasikan pada sistem ini karena sudah diperuntukkan oleh anggota tim yang lain. Pada sistem ini terdapat fitur notifikasi sebagai bentuk implementasi dari konsep hubungan supplier relationship management atau SRM antara supplier dan perusahaan. Dalam fitur notifikasi supplier tidak hanya mengetahui sisa stok barang mereka yang ada di gudang perusahaan tapi juga terdapat informasi barang apa saja yang direkomendasikan oleh perusahaan untuk tidak dikirim ulang karena minat barang dari konsumen tidak terlalu tinggi sehingga dapat mengurangi biaya pengiriman yang percuma.

\section{Tampilan Menu Supplier}

Menu supplier diperlihatkan pada Gambar 3. Menu supplier digunakan untuk melakukan pendataan pada supplier. Pada menu supplier terdapat data berupa nama supplier, kode supplier, nomor telepon supplier, dan alamat supplier. Pada halaman ini juga admin dapat melakukan tambah data supplier, mengubah data supplier, melihat detail supplier, dan menghapus supplier. Admin dapat melakukan pencarian data supplier lewat search dengan memasukkan nama supplier atau kode supplier yang ingin di cari.

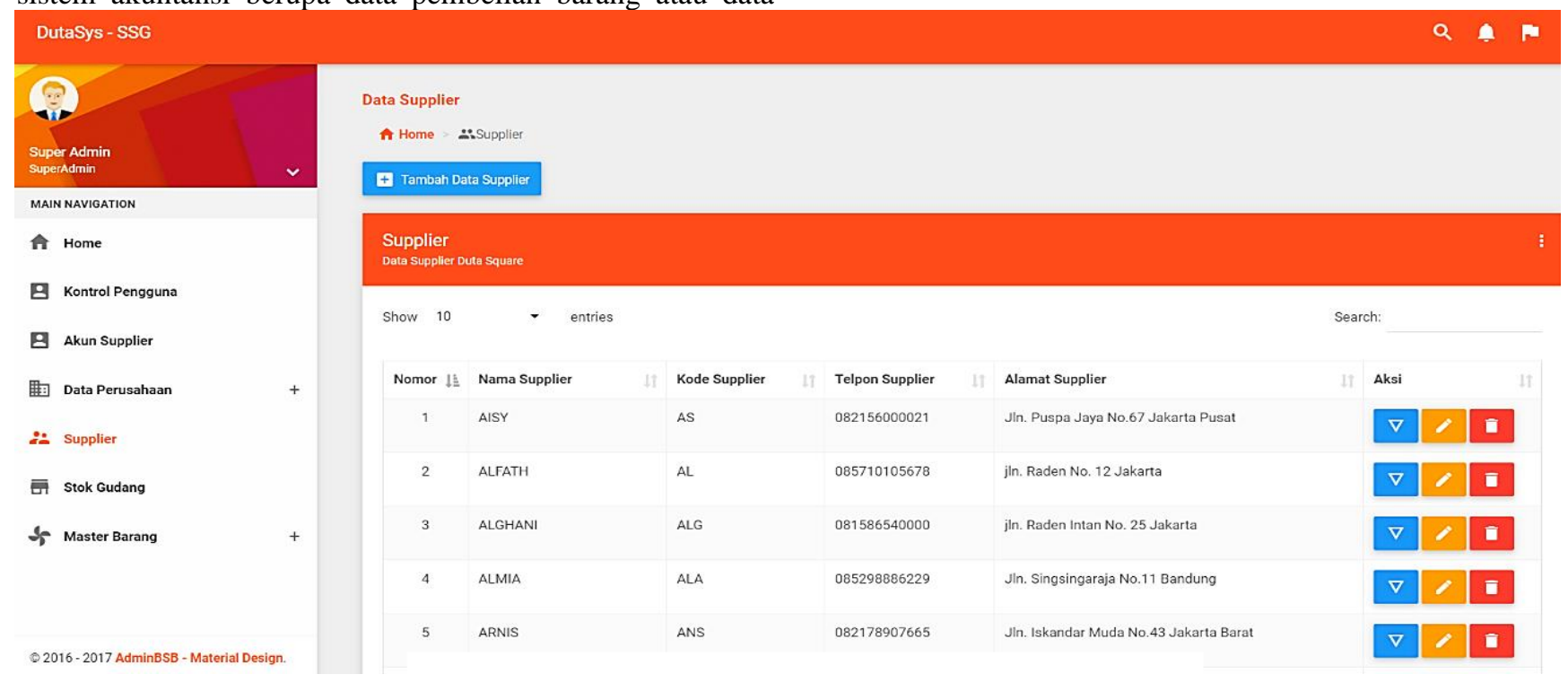

Gambar 3. Tampilan halaman supplier. 


\section{Tampilan Menu Jenis Kode Barang}

Halaman tampilan menu jenis kode barang diperlihatkan pada Gambar 4. Menu jenis kode barang di gunakan untuk membuat kode barang misal kode 001 sebagai kode untuk pakaian pria ukuran S. Pada menu jenis kode barang terdapat data berupa nomor, nama kode barang, dan keterangan tentang jenis kode barang yang diinputkan. Pada halaman ini admin dapat melakukan tambah data jenis kode barang, mengubah, dan melihat detail jenis kode barang, dan menghapus jenis kode barang. Admin dapat melakukan pencarian data kode barang lewat search dengan memasukkan kode barang.

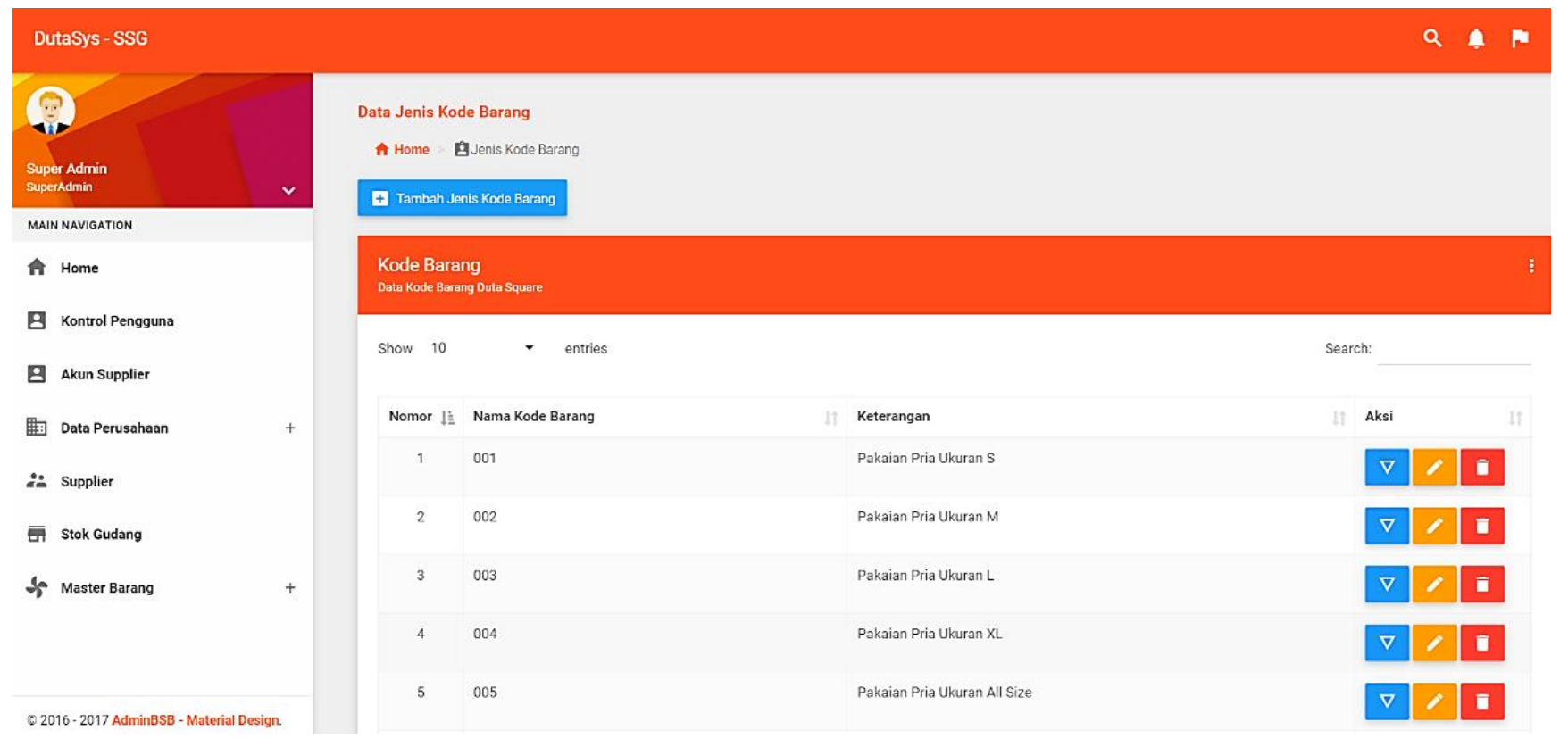

Gambar 4. Tampilan halaman kode jenis barang.

\section{Tampilan Menu Kategori Barang}

Menu kategori barang diperlihatkan pada Gambar 5. Menu kategori digunakan untuk membuat kategori barang misalnya kategori baju anak yang berisikan pakaian anak. Pada menu kategori terdapat data berupa nama kategori dan keterangan tentang kategori yang di- inputkan. Pada halaman ini admin dapat melakukan tambah data kategori barang, mengubah, dan melihat detail kategori barang, dan menghapus kategori barang. Admin dapat melakukan pencarian data lewat search dengan memasukkan nama kategori.

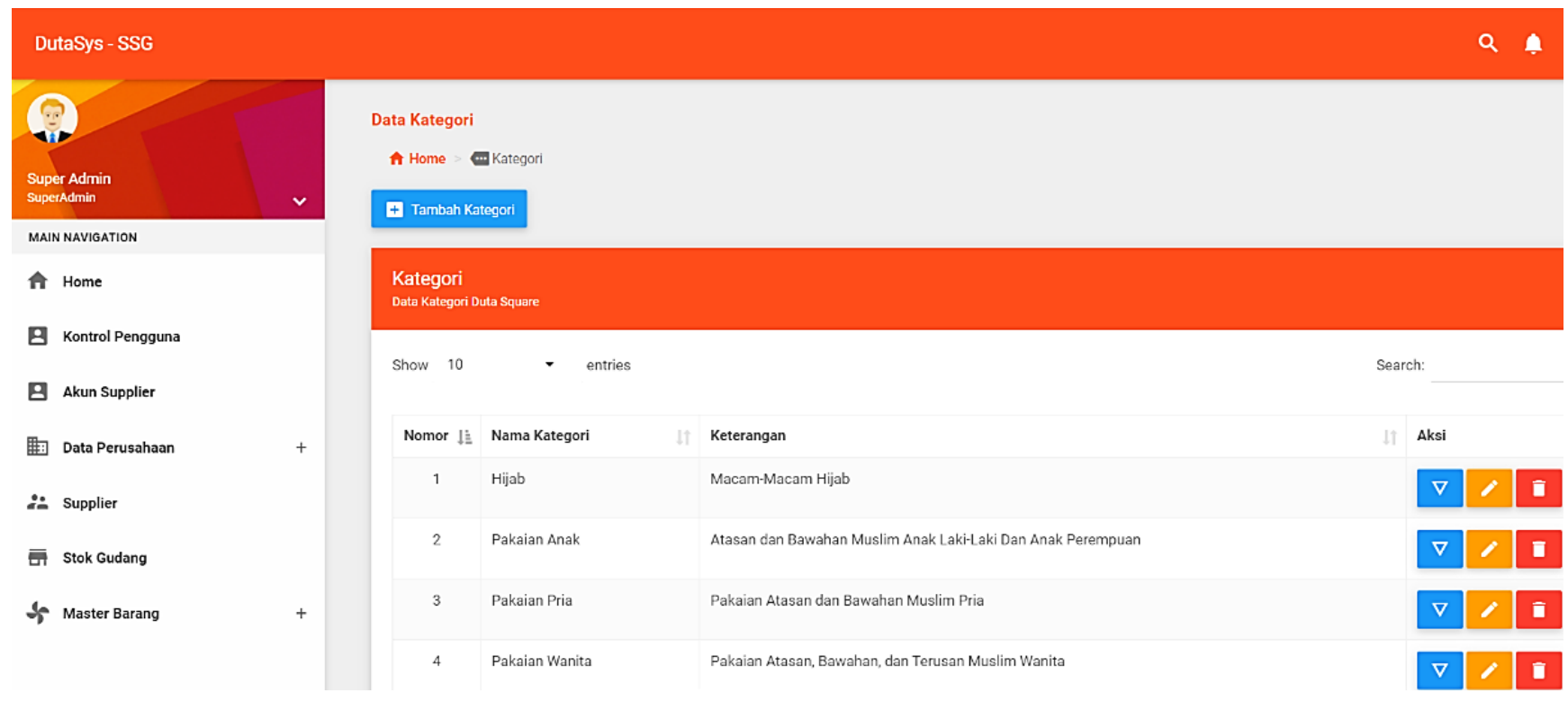

Gambar 5. Tampilan halaman kategori barang. 


\section{Tampilan Menu Barang}

Menu barang diperlihatkan pada Gambar 6. Menu barang digunakan untuk mendata barang yang telah sampai di gudang dan sudah dilakukan pengecekan oleh pegawai perusahaan. Pada menu barang terdapat data berupa nomor, kode barang, nama barang, harga barang, dan juga jumlah stok barang yang ada di gudang. Pada halaman ini juga admin dapat melakukan tambah data, mengubah, melihat detail, dan menghapus barang. Admin dapat melakukan pencarian data barang lewat search dengan memasukkan nama barang atau kode barang.

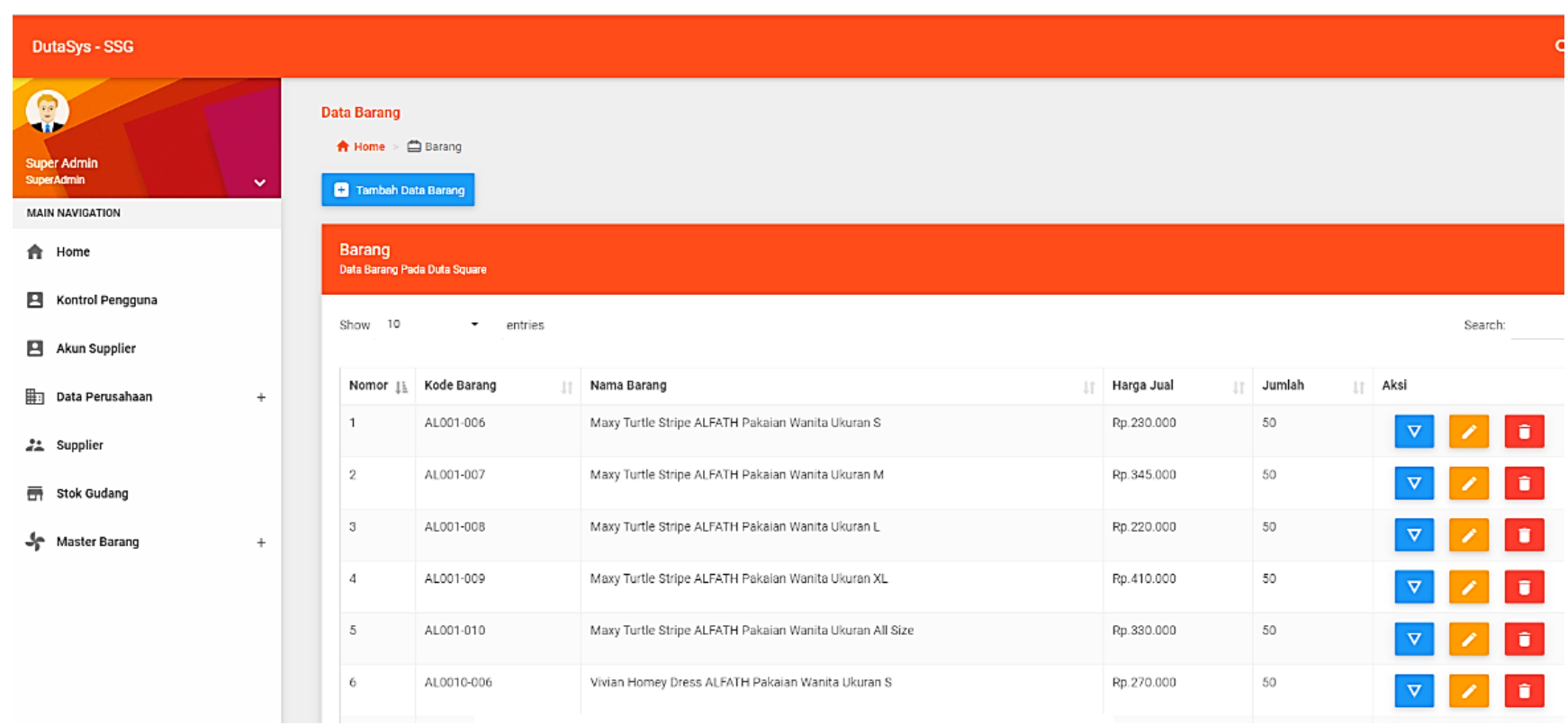

Gambar 6. Tampilan halaman barang.

\section{Tampilan Menu Stok Gudang}

Menu stok gudang diperlihatkan pada Gambar 7 . Menu stok gudang digunakan untuk mengetahui keseluruhan stok barang yang ada di gudang. Pada menu stok gudang terdapat data berupa jumlah barang yang ada di gudang, jumlah supplier, jumlah rak barang yang ada di gudang, nama barang, kode barang, nama supplier, nama satuan, nama kategori barang, dan jumlah stok barang. Pada halaman ini, admin hanya dapat melihat detail stok barang. Admin dapat melakukan pencarian data untuk melihat stok pada fitur search dengan memasukkan kata kunci berupa nama barang, kode barang, atau nama supplier.

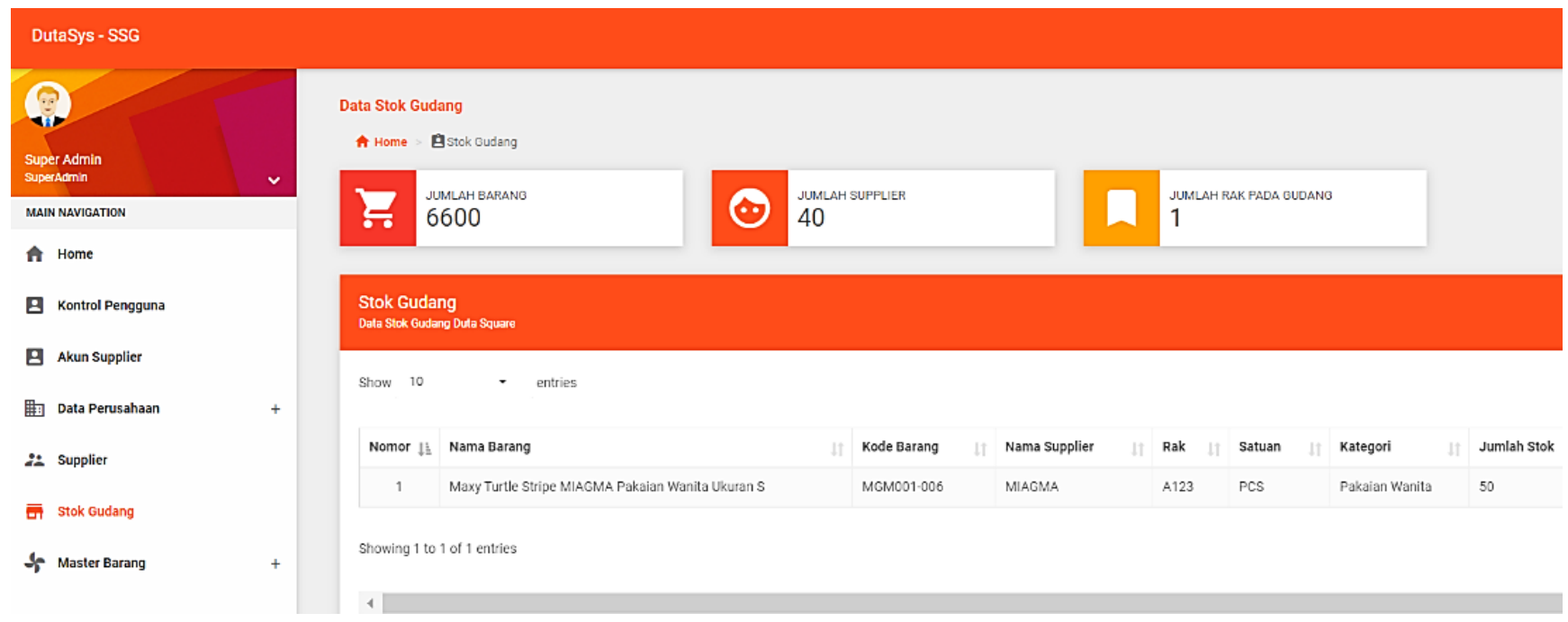

Gambar 7. Tampilan menu stok gudang. 


\section{Tampilan Menu Satuan}

Tampilan menu satuan diperlihatkan pada Gambar 8. Menu satuan digunakan untuk membuat satuan barang misalnya satuan pcs, gr, dan ml. Pada menu satuan barang terdapat data berupa nomor, nama satuan, dan keterangan tentang satuan barang yang diinputkan.
Pada halaman ini, admin dapat melakukan tambah data satuan barang, mengubah satuan barang, melihat detail satuan barang, dan menghapus satuan barang. Admin dapat melakukan pencarian data satuan barang lewat fitur search dengan memasukkan kata kunci berupa nama satuan.

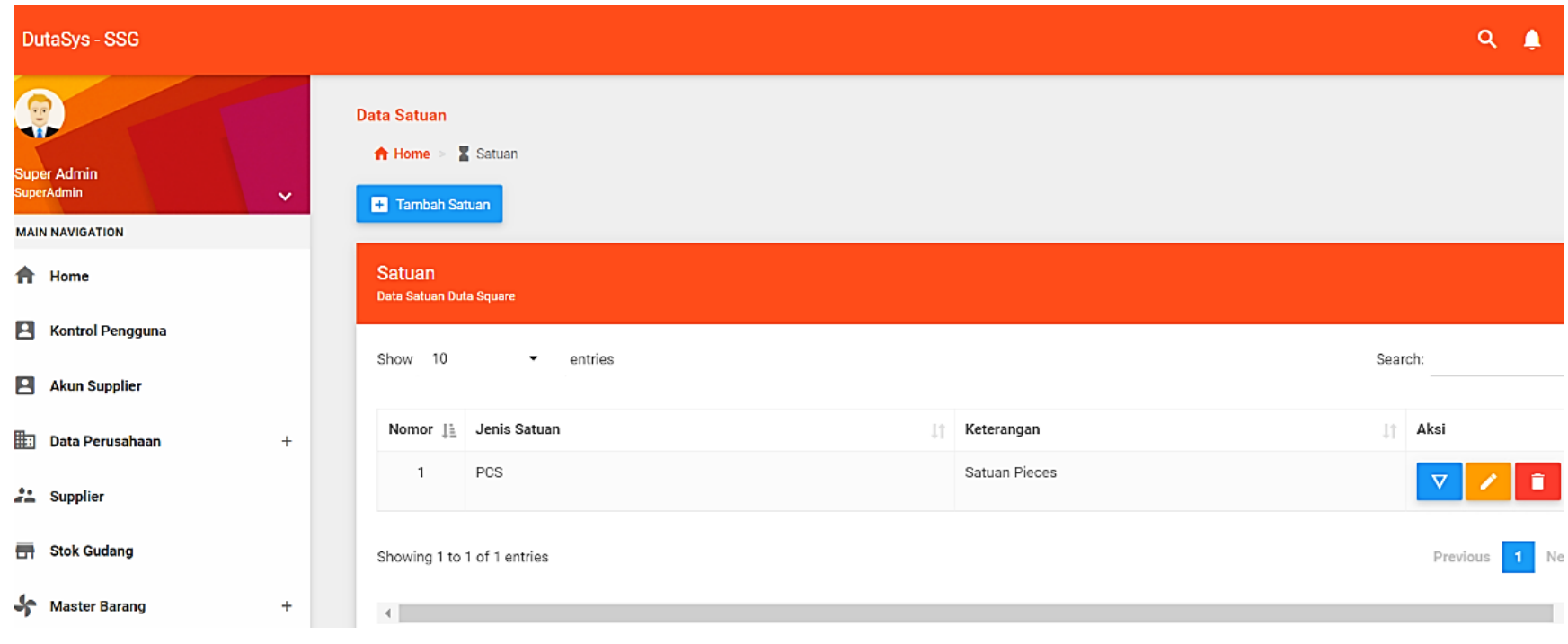

Gambar 8. Tampilan halaman menu satuan.

7. Tampilan Menu Transaksi Pengiriman Pembelian Tampilan transaksi pengiriman diperlihatkan pada Gambar 10. Menu ini dapat dikatakan sebagai laporan pembelian barang dari supplier karena dilakukan pendataan pembelian barang dari supplier. Pada menu transaksi terdapat transaksi pembelian barang yang belum sampai di perusahaan dan pembelian barang yang telah sampai di perusahaan.
Barang yang sampai di perusahaan akan memiliki faktur sebagai data pembelian. Pada data transaksi tersebut terdapat data tanggal kirim, tanggal terima, nomor faktur, dan konfirmasi status. Pada halaman ini, admin dapat melakukan tambah data transaksi, mengubah, melihat detail, dan menghapus transaksi. Admin dapat melakukan pencarian data transaksi lewat search dengan memasukkan tanggal kirim atau nomor faktur.

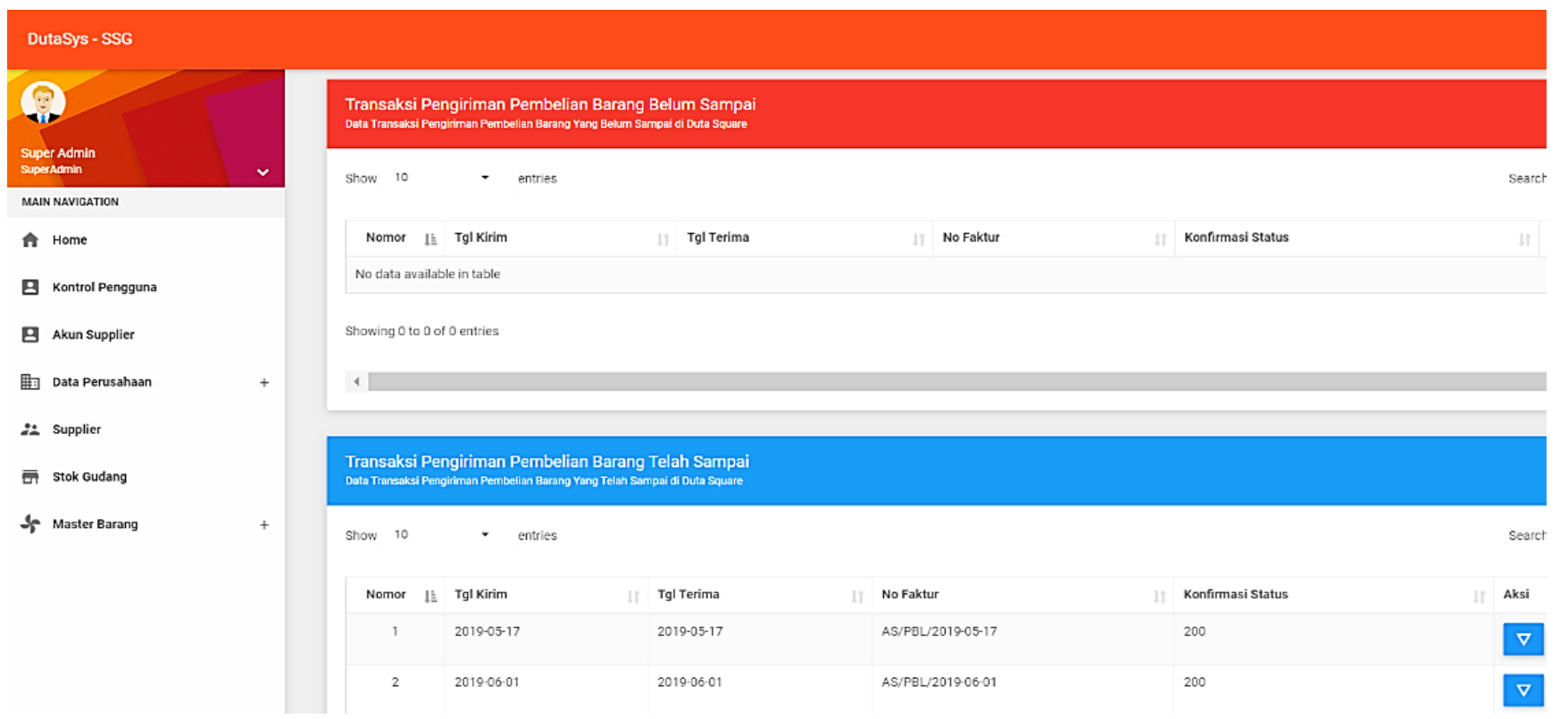

Gambar 9. Tampilan halaman menu transaksi pengiriman pembelian barang. 
8. Tampilan Menu Rak Gudang

Tampilan rak gudang diperlihatkan pada Gambar 9. Menu rak gudang digunakan untuk membuat rak yang nantinya akan di isi daftar barang. Pada menu rak gudang terdapat data berupa nama rak gudang, dan keterangan tentang rak gudang contohnya yaitu kode A1 adalah kode rak untuk baju muslim anak. Pada halaman rak, admin dapat melakukan tambah data rak barang, mengubah rak barang, melihat detail rak barang, dan menghapus rak barang. Admin dapat melakukan pencarian data satuan barang lewat search dengan memasukkan kata kunci berupa nama rak.

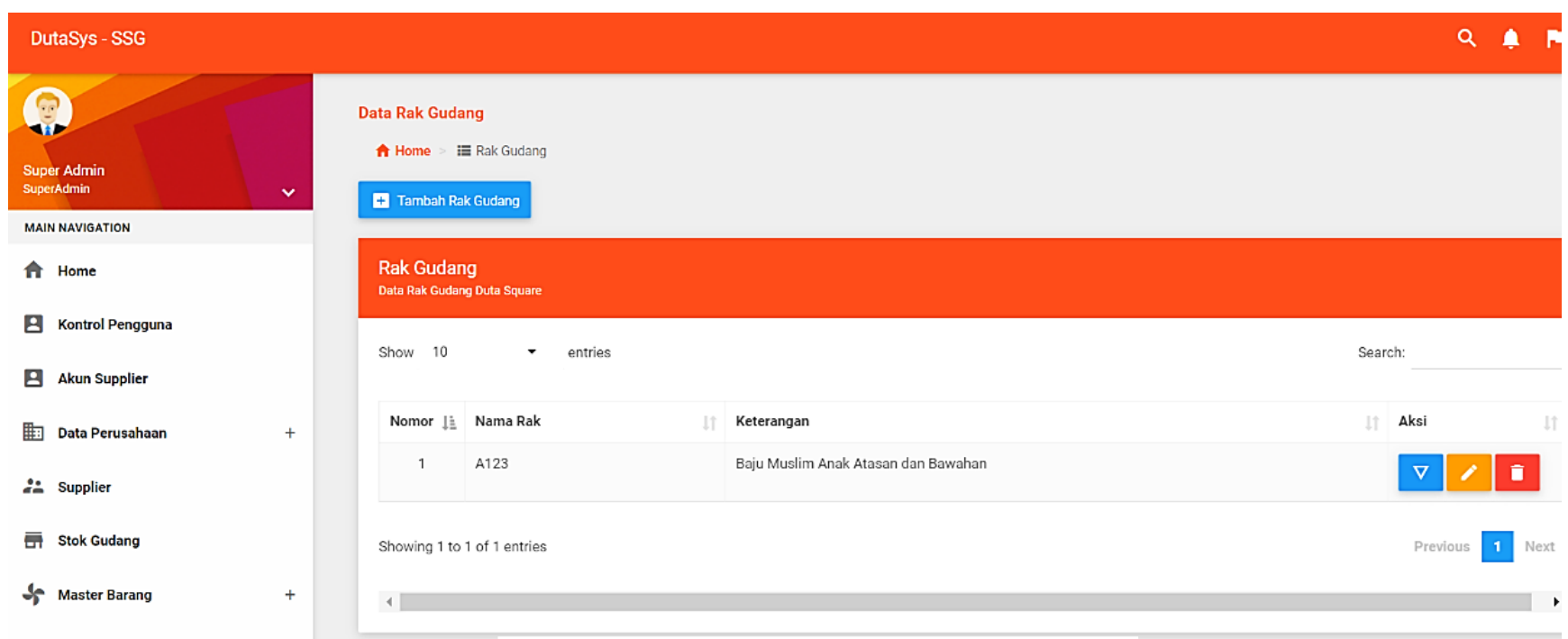

Gambar 100. Tampilan halaman menu return barang.

\section{Tampilan Menu Return Barang}

Tampilan return barang diperlihatkan pada Gambar 11. Menu return digunakan untuk mendata pengembalian barang (return) ke supplier ketika terdapat barang yang rusak/reject. Pada menu return barang terdapat data berupa tanggal kirim, tanggal terima, nomor faktur, dan konfirmasi status.
Pada halaman ini, admin dapat melakukan tambah data return barang dan melihat detail return barang. Admin dapat melakukan pencarian data return lewat search dengan memasukkan tanggal kirim atau nomor faktur. Ketika barang yang di-return sampai admin memilih tombol konfirmasi barang sampai.

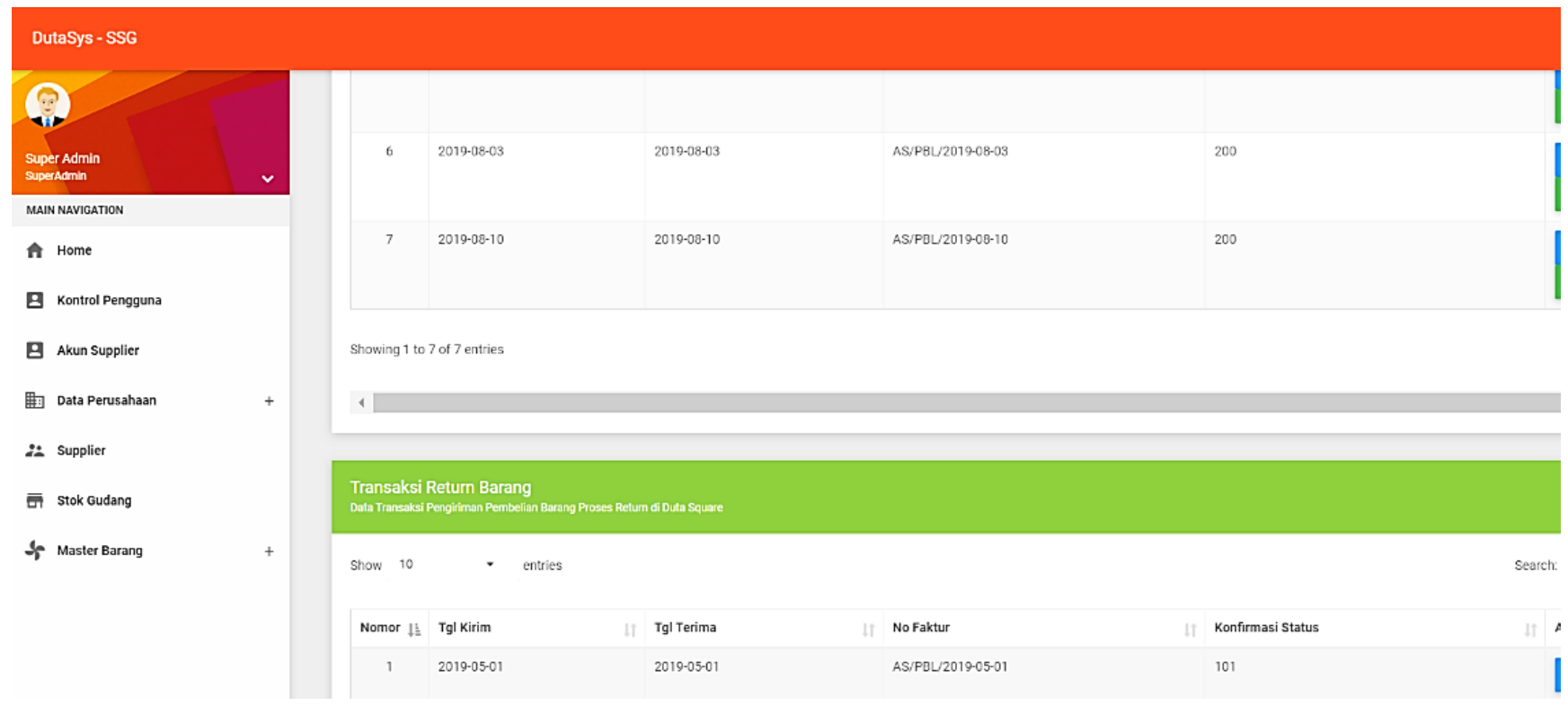

Gambar 9. Tampilan halaman menu return barang. 


\section{Tampilan Menu Notifikasi}

Tampilan notifikasi diperlihatkan pada Gambar 12 . Menu notifikasi hanya dapat diakses oleh role supplier. Menu notifikasi digunakan untuk memberitahukan kepada supplier saat barang mereka hampir habis di gudang atau mencapai batas minimal. Fitur ini dibuat sebagai implementasi dari supplier relationship management, karena sebelumnya banyak supplier yang mengirimkan barang mereka ke perusahaan dengan inisiatif sediri sehingga terjadi penumpukan stok di gudang.
Dengan adanya fitur ini diharapkan dapat meminimalisir miss comunication antara supplier dan owner serta dapat membangun hubungan yang baik antara supplier dan perusahaan. Pada menu notifikasi terdapat pemberitahuan jumlah barang yang stoknya hampir habis. Pada halaman tersebut juga terdapat nama barang yang jumlahnya hampir habis di gudang dan dapat ditawarkan kembali kepada owner untuk dilakukan restock barang atau tidak. Supplier hanya dapat melihat tampilan halaman notifikasi tanpa bisa menambah, mengubah, atau menghapus data notifikasi.

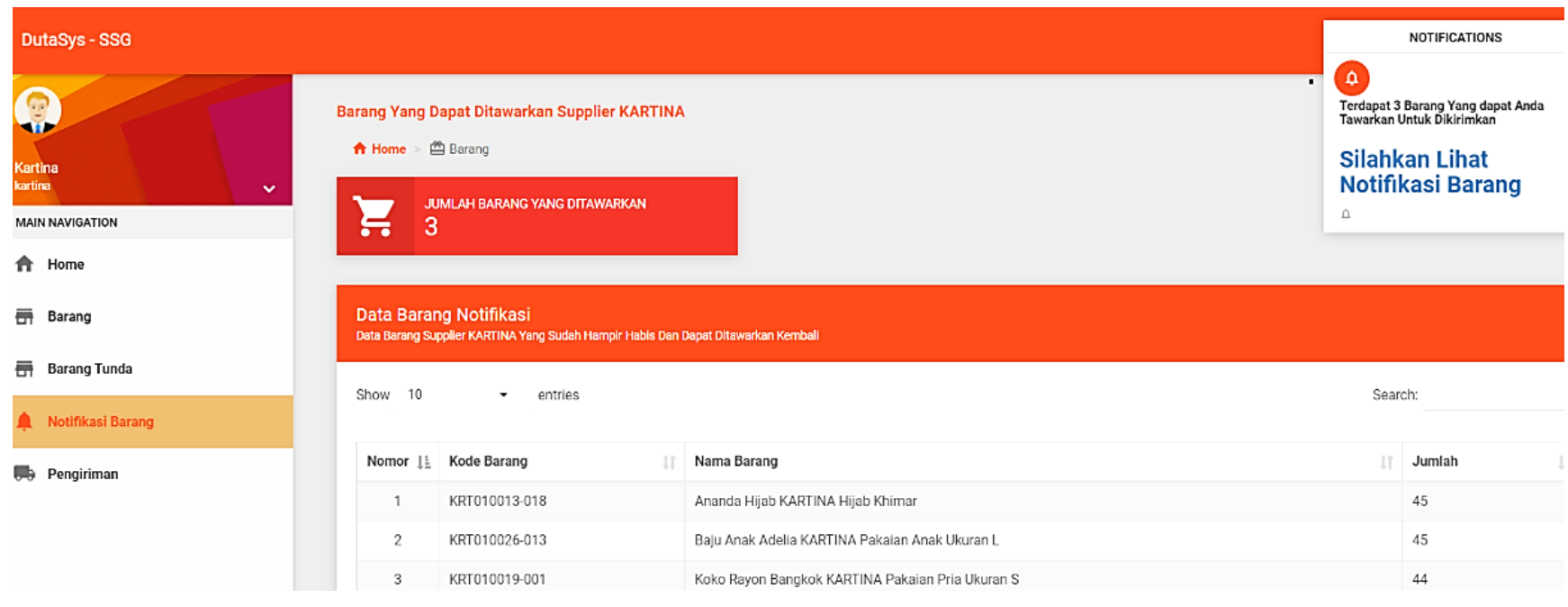

Gambar 12. Tampilan halaman menu notifikasi.

11. Tampilan Menu Barang Tunda

Tampilan menu barang tunda diperlihatkan pada Gambar 13. Selain fitur notifikasi, fitur ini juga salah satu implementasi dari supplier relationship management. Tampilan menu barang tunda digunakan untuk memberitahukan kepada supplier barang yang tidak perlu dikirim ulang ke perusahaan. Data barang tersebut masuk kedalam barang tunda karena termasuk barang yang tidak diminati pembeli. Supplier yang mengetahui daftar barang tunda tersebut, tidak perlu melakukan pengiriman barang yang ada di daftar barang tunda sehingga dapat menghemat biaya pengiriman atau biaya produksi yang dikeluarkan. Supplier hanya dapat melihat tampilan tanpa bisa menambah, mengubah, atau menghapus data.

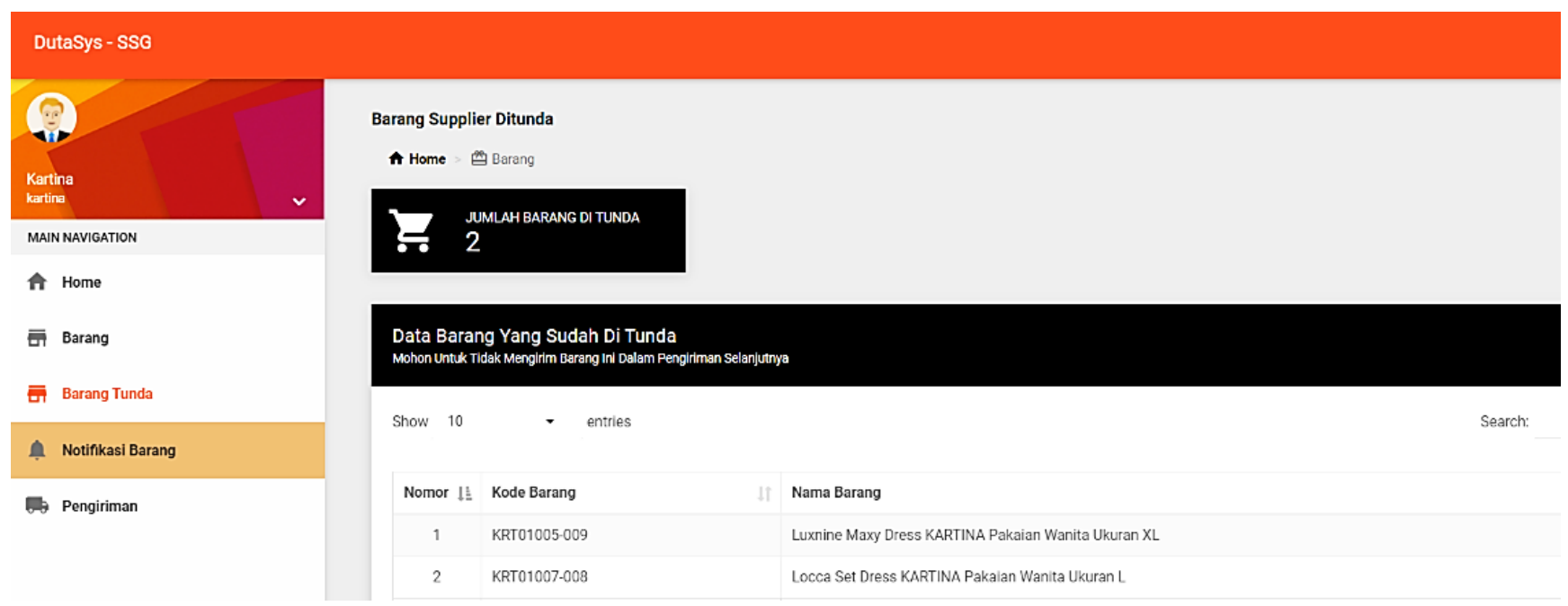

Gambar 13. Tampilan halaman menu barang tunda. 


\section{Pengujian Sistem}

\section{Black Box Testing}

Black-box testing adalah metode pengujian perangkat lunak yang tes fungsionalitas dari aplikasi atau sistem. Metode Black-box berfokus pada keperluan fungsional yang dibutuhkan oleh software. Black-Box testing merupakan pengujian yang berfokus pada spesifikasi fungsional dari perangkat lunak, tester dapat mendefinisikan kumpulan kondisi input dan melakukan pengetesan pada spesifikasi fungsional program [17]. Pengujian ini menguji dua role user yang ada pada sistem yaitu admin dan supplier. Hasil dari pengujian yang telah dilakukan yaitu sistem telah berhasil memenuhi kebutuhan pengguna dan dapat mengidentifikasi kesalahan dengan menampilkan pesan error.

Pengujian untuk peran/role admin diperlihatkan pada Tabel I. Tabel I menunjukkan pengujian sistem pada aktor admin telah berfungsi sesuai keinginan pengguna dari user stories. Fitur-fitur yang diuji pada bagian aktor admin gudang yaitu pendataan supplier, pendataan barang, pendataan transaksi pembelian barang dari supplier dan pendataan return barang pembelian dari supplier.

TABEL I

PENGUJIAN Sistem Peran ADMin

\begin{tabular}{|c|c|c|c|c|c|c|}
\hline No & $\begin{array}{c}\text { Kelas } \\
\text { Uji }\end{array}$ & $\begin{array}{c}\text { Daftar } \\
\text { Pengujian }\end{array}$ & $\begin{array}{c}\text { Skenario } \\
\text { Uji }\end{array}$ & $\begin{array}{c}\text { Hasil } \\
\text { yang } \\
\text { diharap } \\
\text { kan }\end{array}$ & $\begin{array}{c}\text { Hasil } \\
\text { yang } \\
\text { didapat } \\
\text { kan }\end{array}$ & Validasi \\
\hline 1. & \begin{tabular}{|l} 
Halaman \\
Menu \\
Stok \\
Gudang
\end{tabular} & $\begin{array}{l}\text { Pengujian } \\
\text { menampilk } \\
\text { an } \\
\text { halaman } \\
\text { stok } \\
\text { gudang. }\end{array}$ & $\begin{array}{l}\text { Klik } \\
\text { pada } \\
\text { menu } \\
\text { stok } \\
\text { gudang. }\end{array}$ & $\begin{array}{l}\text { Menampi } \\
\text { lkan } \\
\text { informasi } \\
\text { stok } \\
\text { barang. }\end{array}$ & \begin{tabular}{|l} 
Sistem \\
dapat \\
menampi \\
lkan \\
informasi \\
stok.
\end{tabular} & VALID \\
\hline \multirow[t]{2}{*}{2.} & \multirow[t]{2}{*}{$\begin{array}{l}\text { Halaman } \\
\text { Menu } \\
\text { Supplier }\end{array}$} & $\begin{array}{l}\text { Pengujian } \\
\text { menampilk } \\
\text { an } \\
\text { halaman } \\
\text { menu } \\
\text { supplier }\end{array}$ & $\begin{array}{l}\text { Klik } \\
\text { pada } \\
\text { menu } \\
\text { supplier }\end{array}$ & $\begin{array}{l}\text { Menampi } \\
\text { lkan data } \\
\text { semua } \\
\text { supplier } \\
\text { dan } \\
\text { tombol } \\
\text { aksi. }\end{array}$ & $\begin{array}{l}\text { Sistem } \\
\text { dapat } \\
\text { menampi } \\
\text { lkan } \\
\text { semua } \\
\text { supplier } \\
\text { dan aksi. }\end{array}$ & VALID \\
\hline & & \begin{tabular}{|l|} 
Pengujian \\
pada \\
tombol \\
"Tambah \\
Data" yang \\
ada \\
dihalaman \\
menu \\
Supplier
\end{tabular} & \begin{tabular}{|l} 
Klik \\
pada \\
tombol \\
tambah \\
data \\
Supplier
\end{tabular} & $\begin{array}{l}\text { Menampi } \\
\text { lkan } \\
\text { form } \\
\text { pengisian } \\
\text { Supplier } \\
\text { baru dan } \\
\text { dapat } \\
\text { menyimp } \\
\text { an data. }\end{array}$ & $\begin{array}{l}\text { Sistem } \\
\text { dapat } \\
\text { menampi } \\
\text { lkan } \\
\text { form } \\
\text { pengisian } \\
\text { dan dapat } \\
\text { menyimp } \\
\text { an data }\end{array}$ & VALID \\
\hline
\end{tabular}

\begin{tabular}{|c|c|c|c|c|c|c|}
\hline \multirow[t]{2}{*}{ No } & $\begin{array}{c}\text { Kelas } \\
\text { Uji }\end{array}$ & \begin{tabular}{|c|} 
Daftar \\
Pengujian
\end{tabular} & $\begin{array}{c}\text { Skenario } \\
\text { Uji }\end{array}$ & \begin{tabular}{|c|} 
Hasil \\
yang \\
diharap \\
kan
\end{tabular} & \begin{tabular}{|c|} 
Hasil \\
yang \\
didapat \\
kan
\end{tabular} & Validasi \\
\hline & & $\begin{array}{l}\text { Pengujian } \\
\text { pada } \\
\text { Tombol } \\
\text { aksi } \\
\text { berupa } \\
\text { ubah, } \\
\text { detail, dan } \\
\text { hapus }\end{array}$ & \begin{tabular}{|l|} 
Klik \\
tombol \\
ubah/ \\
hapus/ \\
detail \\
pada data \\
Supplier
\end{tabular} & \begin{tabular}{|l|} 
Menampi \\
lkan data \\
Supplier \\
yang \\
akan \\
diubah/ \\
dihapus/ \\
melihat \\
detail
\end{tabular} & \begin{tabular}{|l|} 
Sistem \\
dapat \\
menampi \\
lkan data \\
Supplier \\
yang di \\
ubah/ di \\
hapus/ \\
melihat \\
detail
\end{tabular} & VALID \\
\hline \multirow[t]{3}{*}{3.} & \multirow[t]{3}{*}{\begin{tabular}{|l} 
Halaman \\
Sub \\
Menu \\
Barang
\end{tabular}} & $\begin{array}{l}\text { Pengujian } \\
\text { menampil } \\
\text { kan } \\
\text { halaman } \\
\text { sub menu } \\
\text { barang. }\end{array}$ & \begin{tabular}{|l|} 
Klik \\
pada \\
menu \\
Master \\
Barang, \\
lalu klik \\
sub \\
menu \\
barang. \\
\end{tabular} & $\begin{array}{l}\text { Menampi } \\
\text { lkan } \\
\text { halaman } \\
\text { yang } \\
\text { berisi } \\
\text { data } \\
\text { barang. }\end{array}$ & \begin{tabular}{|l|} 
Sistem \\
dapat \\
menampi \\
lkan \\
halaman \\
yang \\
berisi \\
data \\
barang. \\
\end{tabular} & VALID \\
\hline & & $\begin{array}{l}\text { Pengujian } \\
\text { pada } \\
\text { tombol } \\
\text { Tambah } \\
\text { Data yang } \\
\text { menu } \\
\text { barang. }\end{array}$ & \begin{tabular}{|l|} 
Klik \\
menu \\
barang, \\
dan klik \\
tombol \\
"Tambah \\
Data" \\
pada \\
barang. \\
\end{tabular} & $\begin{array}{l}\text { Menampi } \\
\text { lkan } \\
\text { form } \\
\text { pengisian } \\
\text { data } \\
\text { barang } \\
\text { baru. }\end{array}$ & \begin{tabular}{|l} 
Sistem \\
dapat \\
menampi \\
lkan \\
form \\
pengisian \\
data \\
barang \\
baru.
\end{tabular} & VALID \\
\hline & & $\begin{array}{l}\text { Pengujian } \\
\text { pada } \\
\text { tombol } \\
\text { aksi } \\
\text { berupa } \\
\text { ubah, } \\
\text { detail, } \\
\text { dan hapus }\end{array}$ & \begin{tabular}{|l|} 
Klik \\
tombol \\
ubah/ \\
hapus/ \\
detail \\
pada data \\
barang
\end{tabular} & $\begin{array}{l}\text { Menampi } \\
\text { lk } \\
\text { kan data } \\
\text { barang } \\
\text { yang } \\
\text { akan } \\
\text { diubah/ } \\
\text { dihapus/ } \\
\text { melihat } \\
\text { detail. }\end{array}$ & \begin{tabular}{|l} 
Sistem \\
dapat \\
menampi \\
1 \\
kan data \\
barang \\
yang \\
akan \\
diubah/ \\
dihapus/ \\
melihat \\
detail.
\end{tabular} & VALID \\
\hline 4. & \begin{tabular}{|l} 
Halaman \\
Sub \\
Menu \\
Rak
\end{tabular} & $\begin{array}{l}\text { Pengujian } \\
\text { menampil } \\
\text { kan } \\
\text { halaman } \\
\text { menu rak } \\
\text { dan data } \\
\text { barang } \\
\text { yang ada } \\
\text { di rak. }\end{array}$ & \begin{tabular}{|l|} 
Klik \\
pada \\
menu \\
rak, dan \\
pilih rak \\
yang \\
akan \\
dilihat.
\end{tabular} & \begin{tabular}{|l|} 
Menamp \\
ilkan \\
halaman \\
yang \\
berisi \\
data \\
barang \\
pada rak \\
yang \\
dipilih.
\end{tabular} & \begin{tabular}{|l} 
Sistem \\
dapat \\
menam \\
pilkan \\
halaman \\
data \\
barang \\
pada rak \\
yang \\
dipilih.
\end{tabular} & VALID \\
\hline
\end{tabular}




\begin{tabular}{|c|c|c|c|c|c|c|}
\hline No & $\begin{array}{c}\text { Kelas } \\
\text { Uji }\end{array}$ & $\begin{array}{c}\text { Daftar } \\
\text { Pengujian }\end{array}$ & $\begin{array}{c}\text { Skenario } \\
\text { Uji }\end{array}$ & $\begin{array}{c}\text { Hasil } \\
\text { yang } \\
\text { diharap } \\
\text { kan }\end{array}$ & \begin{tabular}{|c|} 
Hasil \\
yang \\
didapat \\
kan
\end{tabular} & Validasi \\
\hline & & $\begin{array}{l}\text { Pengujian } \\
\text { pada } \\
\text { tombol } \\
\text { "Tambah } \\
\text { Rak" }\end{array}$ & \begin{tabular}{|l} 
Klik \\
menu \\
rak, dan \\
klik \\
tombol \\
tambah \\
rak.
\end{tabular} & $\begin{array}{l}\text { Menampi } \\
\text { lkan } \\
\text { form } \\
\text { pengisian } \\
\text { tambah } \\
\text { rak. }\end{array}$ & \begin{tabular}{|l|} 
Sistem \\
dapat \\
menampi \\
llkan \\
form \\
pengisian \\
tambah \\
rak.
\end{tabular} & VALID \\
\hline & & $\begin{array}{l}\text { Pengujia } \\
\text { n pada } \\
\text { tombol } \\
\text { aksi } \\
\text { berupa } \\
\text { ubah, } \\
\text { detail, } \\
\text { dan } \\
\text { hapus }\end{array}$ & $\begin{array}{l}\text { Klik } \\
\text { tombol } \\
\text { ubah/ } \\
\text { hapus/ } \\
\text { detail } \\
\text { pada } \\
\text { data } \\
\text { rak. }\end{array}$ & $\begin{array}{l}\text { Mena } \\
\text { mpilka } \\
\text { n data } \\
\text { rak } \\
\text { yang } \\
\text { akan } \\
\text { diubah } \\
\text { / } \\
\text { dihapu } \\
\text { s/ } \\
\text { meliha } \\
\text { t detail }\end{array}$ & $\begin{array}{l}\text { Sistem } \\
\text { dapat } \\
\text { mena } \\
\text { mp } \\
\text { ilkan } \\
\text { data } \\
\text { rak } \\
\text { yang } \\
\text { akan } \\
\text { diubah } \\
\text { / } \\
\text { dihapu } \\
\text { s/ lihat } \\
\text { detail }\end{array}$ & VALID \\
\hline 5. & $\begin{array}{l}\text { Hala } \\
\text { man } \\
\text { Sub } \\
\text { Menu } \\
\text { Satua } \\
\text { n }\end{array}$ & $\begin{array}{l}\text { Pengujia } \\
\mathrm{n} \\
\text { menamp } \\
\text { ilkan } \\
\text { halaman } \\
\text { satuan }\end{array}$ & $\begin{array}{l}\text { Klik } \\
\text { pada } \\
\text { menu } \\
\text { menu } \\
\text { satuan. }\end{array}$ & $\begin{array}{l}\text { Mena } \\
\text { mpilka } \\
\mathrm{n} \\
\text { halama } \\
\mathrm{n} \text { data } \\
\text { satuan. }\end{array}$ & $\begin{array}{l}\text { Sistem } \\
\text { dapat } \\
\text { mena } \\
\text { mpilka } \\
\mathrm{n} \\
\text { halama } \\
\mathrm{n} \text { data } \\
\text { satuan. } \\
\end{array}$ & VALID \\
\hline & & $\begin{array}{l}\text { Pengujia } \\
\text { n pada } \\
\text { tombol } \\
\text { "Tamba } \\
\text { h } \\
\text { Satuan" } \\
\text { yang } \\
\text { ada } \\
\text { dihalam } \\
\text { an sub } \\
\text { menu } \\
\text { satuan. }\end{array}$ & $\begin{array}{l}\text { Klik } \\
\text { menu } \\
\text { satuan, } \\
\text { dan } \\
\text { klik } \\
\text { tombol } \\
\text { tamba } \\
\text { h } \\
\text { satuan. }\end{array}$ & $\begin{array}{l}\text { Mena } \\
\text { mpilka } \\
\mathrm{n} \text { form } \\
\text { pengisi } \\
\text { an } \\
\text { untuk } \\
\text { mena } \\
\text { mbah } \\
\text { satuan. }\end{array}$ & 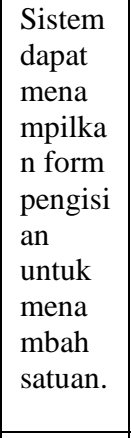 & VALID \\
\hline & & $\begin{array}{l}\text { Pengujia } \\
\text { n pada } \\
\text { tombol } \\
\text { Aksi } \\
\text { berupa } \\
\text { ubah, } \\
\text { detail, } \\
\text { dan } \\
\text { hapus }\end{array}$ & $\begin{array}{l}\text { Klik } \\
\text { tombol } \\
\text { ubah/ } \\
\text { hapus/ } \\
\text { detail } \\
\text { pada } \\
\text { data } \\
\text { satuan. }\end{array}$ & $\begin{array}{l}\text { Mena } \\
\text { mpilka } \\
\text { n data } \\
\text { yang } \\
\text { akan } \\
\text { diubah } \\
\text { / } \\
\text { dihapu } \\
\text { s/ } \\
\text { meliha } \\
\text { t detail }\end{array}$ & $\begin{array}{l}\text { Sistem } \\
\text { dapat } \\
\text { mena } \\
\text { mpilka } \\
\text { n data } \\
\text { yang } \\
\text { akan } \\
\text { diubah } \\
\text { / } \\
\text { dihapu } \\
\text { s/ lihat } \\
\text { detail } \\
\end{array}$ & VALID \\
\hline
\end{tabular}

\begin{tabular}{|c|c|c|c|c|c|c|}
\hline No & $\begin{array}{c}\text { Kelas } \\
\text { Uji }\end{array}$ & $\begin{array}{c}\text { Daftar } \\
\text { Pengujian }\end{array}$ & $\begin{array}{c}\text { Skenario } \\
\text { Uji }\end{array}$ & \begin{tabular}{|c|} 
Hasil \\
yang \\
diharap \\
kan
\end{tabular} & $\begin{array}{c}\text { Hasil } \\
\text { yang } \\
\text { didapat } \\
\text { kan }\end{array}$ & Validasi \\
\hline \multirow[t]{3}{*}{6.} & \multirow[t]{2}{*}{$\begin{array}{l}\text { Hala } \\
\text { man } \\
\text { Menu } \\
\text { Kateg } \\
\text { ori }\end{array}$} & $\begin{array}{l}\text { Pengujia } \\
\mathrm{n} \\
\text { menamp } \\
\text { ilkan } \\
\text { halaman } \\
\text { sub } \\
\text { menu } \\
\text { kategori }\end{array}$ & $\begin{array}{l}\text { Klik } \\
\text { pada } \\
\text { menu } \\
\text { katego } \\
\text { ri }\end{array}$ & $\begin{array}{l}\text { Mena } \\
\text { mpilka } \\
\mathrm{n} \\
\text { halama } \\
\text { n data } \\
\text { katego } \\
\text { ri. }\end{array}$ & $\begin{array}{l}\text { Sistem } \\
\text { dapat } \\
\text { mena } \\
\mathrm{m} \\
\text { pilkan } \\
\text { halama } \\
\text { n data } \\
\text { katego } \\
\text { ri. }\end{array}$ & VALID \\
\hline & & $\begin{array}{l}\text { Pengujia } \\
\text { n pada } \\
\text { tombol } \\
\text { "Tamba } \\
\text { h } \\
\text { kategori } \\
\text { " } \\
\text { dihalam } \\
\text { an sub } \\
\text { menu } \\
\text { kategori }\end{array}$ & $\begin{array}{l}\text { Klik } \\
\text { menu } \\
\text { katego } \\
\text { ri, dan } \\
\text { klik } \\
\text { tombol } \\
\text { tamba } \\
\text { h } \\
\text { katego } \\
\text { ri. }\end{array}$ & $\begin{array}{l}\text { Mena } \\
\text { mpilka } \\
\mathrm{n} \text { form } \\
\text { pengisi } \\
\text { an } \\
\text { mena } \\
\text { mbah } \\
\text { katego } \\
\text { ri. }\end{array}$ & $\begin{array}{l}\text { Sistem } \\
\text { dapat } \\
\text { mena } \\
\text { mpilka } \\
\mathrm{n} \text { form } \\
\text { pengisi } \\
\text { an } \\
\text { katego } \\
\text { ri }\end{array}$ & VALID \\
\hline & & $\begin{array}{l}\text { Pengujia } \\
\text { n pada } \\
\text { tombol } \\
\text { Aksi } \\
\text { berupa } \\
\text { ubah, } \\
\text { detail, } \\
\text { dan } \\
\text { hapus. }\end{array}$ & $\begin{array}{l}\text { Klik } \\
\text { tombol } \\
\text { ubah/ } \\
\text { hapus/ } \\
\text { detail } \\
\text { pada } \\
\text { data } \\
\text { katego } \\
\text { ri }\end{array}$ & \begin{tabular}{|l} 
Mena \\
mpilka \\
$\mathrm{n}$ data \\
yang \\
akan \\
diubah \\
/ \\
dihapu \\
s/ \\
meliha \\
$\mathrm{t}$ \\
detail.
\end{tabular} & $\begin{array}{l}\text { Sistem } \\
\text { dapat } \\
\text { mena } \\
\text { mpilka } \\
\text { n data } \\
\text { yang } \\
\text { akan } \\
\text { diubah } \\
\text { / } \\
\text { dihapu } \\
\text { s/ } \\
\text { meliha } \\
\text { t } \\
\text { detail. }\end{array}$ & VALID \\
\hline \multirow[t]{2}{*}{7.} & \multirow[t]{2}{*}{$\begin{array}{l}\text { Hala } \\
\text { man } \\
\text { Menu } \\
\text { Pengi } \\
\text { riman } \\
\text { Pemb } \\
\text { elian } \\
\text { Baran } \\
\mathrm{g}\end{array}$} & $\begin{array}{l}\text { Pengujia } \\
\text { n } \\
\text { menamp } \\
\text { ilkan } \\
\text { halaman } \\
\text { transaks } \\
\text { i } \\
\text { pembeli } \\
\text { an } \\
\text { barang }\end{array}$ & $\begin{array}{l}\text { Klik } \\
\text { pada } \\
\text { halama } \\
\text { n } \\
\text { transak } \\
\text { si } \\
\text { pengiri } \\
\text { man } \\
\text { pembe } \\
\text { lian } \\
\text { barang } \\
\text {. }\end{array}$ & $\begin{array}{l}\text { Mena } \\
\text { mpilka } \\
\mathrm{n} \\
\text { halama } \\
\mathrm{n} \\
\text { yang } \\
\text { berisi } \\
\text { data } \\
\text { pengiri } \\
\text { man } \\
\text { pembe } \\
\text { lian } \\
\text { barang } \\
\text {. }\end{array}$ & $\begin{array}{l}\text { Sistem } \\
\text { dapat } \\
\text { mena } \\
\text { mpilka } \\
\mathrm{n} \\
\text { halama } \\
\mathrm{n} \\
\text { yang } \\
\text { berisi } \\
\text { data } \\
\text { pengiri } \\
\text { man } \\
\text { pembe } \\
\text { lian } \\
\text { barang }\end{array}$ & VALID \\
\hline & & $\begin{array}{l}\text { Pengujia } \\
\text { n pada } \\
\text { tombol } \\
\text { "Tamba } \\
\text { h Data" } \\
\text { dihalam } \\
\text { an }\end{array}$ & $\begin{array}{l}\text { Klik } \\
\text { pada } \\
\text { transak } \\
\text { si } \\
\text { pengiri } \\
\text { man } \\
\text { dan } \\
\end{array}$ & \begin{tabular}{|l|} 
Mena \\
mpil \\
kan \\
form \\
pengisi \\
an data \\
pengiri \\
\end{tabular} & $\begin{array}{l}\text { Sistem } \\
\text { dapat } \\
\text { mena } \\
\text { mpil } \\
\text { kan } \\
\text { form } \\
\text { pengisi }\end{array}$ & VALID \\
\hline
\end{tabular}




\begin{tabular}{|c|c|c|c|c|c|c|}
\hline No & $\begin{array}{c}\text { Kelas } \\
\text { Uji }\end{array}$ & \begin{tabular}{|c|} 
Daftar \\
Pengujian
\end{tabular} & $\begin{array}{c}\text { Skenario } \\
\text { Uji }\end{array}$ & \begin{tabular}{|c|} 
Hasil \\
yang \\
diharap \\
kan
\end{tabular} & \begin{tabular}{|c|} 
Hasil \\
yang \\
didapat \\
kan
\end{tabular} & Validasi \\
\hline & & $\begin{array}{l}\text { pengiri } \\
\text { man } \\
\text { pembeli } \\
\text { an } \\
\text { barang }\end{array}$ & $\begin{array}{l}\text { klik } \\
\text { tombol } \\
\text { "Tamb } \\
\text { ah } \\
\text { Data" }\end{array}$ & $\begin{array}{l}\text { man } \\
\text { baru }\end{array}$ & $\begin{array}{l}\text { an data } \\
\text { baru }\end{array}$ & \\
\hline & & $\begin{array}{l}\text { Pengujia } \\
\text { n pada } \\
\text { tombol } \\
\text { Aksi } \\
\text { berupa } \\
\text { ubah, } \\
\text { detail, } \\
\text { dan } \\
\text { hapus }\end{array}$ & $\begin{array}{l}\text { Klik } \\
\text { tombol } \\
\text { ubah/ } \\
\text { hapus/ } \\
\text { detail } \\
\text { pada } \\
\text { data } \\
\text { pengiri } \\
\text { man. }\end{array}$ & $\begin{array}{l}\text { Mena } \\
\text { mpilka } \\
\text { n data } \\
\text { yang } \\
\text { akan } \\
\text { diubah } \\
\text { / } \\
\text { dihapu } \\
\text { s/ } \\
\text { meliha } \\
\text { t detail }\end{array}$ & \begin{tabular}{|l|} 
Sistem \\
dapat \\
mena \\
mpilka \\
n data \\
yang \\
akan \\
diubah \\
/ \\
dihapu \\
s/ lihat \\
detail \\
\end{tabular} & VALID \\
\hline \multirow[t]{3}{*}{8.} & \multirow[t]{2}{*}{$\begin{array}{l}\text { Halama } \\
\mathrm{n} \\
\text { Return }\end{array}$} & $\begin{array}{l}\text { Pengujia } \\
\mathrm{n} \\
\text { menamp } \\
\text { ilkan } \\
\text { halaman } \\
\text { Return. }\end{array}$ & $\begin{array}{l}\text { Klik } \\
\text { pada } \\
\text { menu } \\
\text { Transa } \\
\text { ks dan } \\
\text { klik } \\
\text { Return } \\
.\end{array}$ & $\begin{array}{l}\text { Mena } \\
\text { mpilka } \\
\mathrm{n} \\
\text { halama } \\
\mathrm{n} \\
\text { berisi } \\
\text { data } \\
\text { Return }\end{array}$ & \begin{tabular}{|l|} 
Sistem \\
dapat \\
mena \\
mpilka \\
$\mathrm{n}$ \\
halama \\
$\mathrm{n}$ \\
Return
\end{tabular} & VALID \\
\hline & & $\begin{array}{l}\text { Pengujia } \\
\text { n pada } \\
\text { tombol } \\
\text { "Tamba } \\
\text { h Data" } \\
\text { Return. }\end{array}$ & $\begin{array}{l}\text { Klik } \\
\text { menu } \\
\text { Return } \\
\text {, dan } \\
\text { klik } \\
\text { tombol } \\
\text { "Tamb } \\
\text { ah } \\
\text { Data". }\end{array}$ & $\begin{array}{l}\text { Mena } \\
\text { mpilka } \\
\mathrm{n} \text { form } \\
\text { pengisi } \\
\text { an data } \\
\text { Return } \\
\text { baru. }\end{array}$ & \begin{tabular}{|l} 
Sistem \\
dapat \\
mena \\
mpilka \\
n form \\
pengisi \\
an data \\
baru
\end{tabular} & VALID \\
\hline & & $\begin{array}{l}\text { Pengujia } \\
\text { n pada } \\
\text { tombol } \\
\text { Aksi } \\
\text { berupa } \\
\text { ubah, } \\
\text { detail, } \\
\text { dan } \\
\text { hapus }\end{array}$ & $\begin{array}{l}\text { Klik } \\
\text { tombol } \\
\text { ubah/ } \\
\text { hapus/ } \\
\text { detail } \\
\text { pada } \\
\text { data } \\
\text { Return } \\
\text {. }\end{array}$ & \begin{tabular}{|l|} 
Mena \\
mpilka \\
n data \\
Return \\
yang \\
akan \\
diubah \\
/ \\
dihapu \\
s/ \\
meliha \\
t detail \\
\end{tabular} & \begin{tabular}{|l|} 
Sistem \\
dapat \\
mena \\
mpilka \\
n data \\
yang \\
akan \\
diubah \\
/ \\
dihapu \\
s/ \\
meliha \\
t detail \\
\end{tabular} & VALID \\
\hline
\end{tabular}

Dari Tabel I, dapat dilihat fitur telah diuji dan didapatkan hasil yang sebenarnya sudah sesuai dengan analisis kebutuhan sistem dan user stories owner. Pengujian ini telah tervalidasi sesuai dengan hasil sebenarnya. Fitur-fitur yang diuji yaitu fitur stok gudang, barang, rak gudang, kategori, satuan, supplier, return barang, dan transaksi pengiriman pembelian. Setiap fitur diuji untuk menampilkan halaman saat admin melakukan perintah/ klik pada fitur tersebut. Pengujian juga dilakukan pada setiap tombol aksi dan hasil yang didapat tombol aksi dapat berjalan sesuai perintah. Pada pengujian ini juga sistem dapat memunculkan pesan error saat muncul kesalahan.

Pengujian sistem untuk peran/role Supplier diperlihatkan pada Tabel II. Tabel II menunjukkan pengujian sistem pada aktor Supplier telah berfungsi sesuai keinginan pengguna. Fitur-fitur yang di uji pada bagian aktor Supplier yaitu fitur barang tunda dan notifikasi.

TABEL II

Penguitan Sistem Peran SuPPLIER

\begin{tabular}{|c|c|c|c|c|c|c|}
\hline No & $\begin{array}{c}\text { Kel } \\
\text { as } \\
\text { Uji }\end{array}$ & $\begin{array}{c}\text { Daftar } \\
\text { Pengu } \\
\text { jian }\end{array}$ & $\begin{array}{c}\text { Skenar } \\
\text { io Uji }\end{array}$ & $\begin{array}{c}\text { Hasil } \\
\text { yang di } \\
\text { harap } \\
\text { kan }\end{array}$ & $\begin{array}{c}\text { Hasil } \\
\text { yang } \\
\text { di } \\
\text { dapat } \\
\text { kan } \\
\end{array}$ & $\begin{array}{c}\text { Valid } \\
\text { asi }\end{array}$ \\
\hline 1. & $\begin{array}{l}\text { Halama } \\
\text { n Menu } \\
\text { Barang }\end{array}$ & $\begin{array}{l}\text { Pengujian } \\
\text { menampil } \\
\text { kan } \\
\text { halaman } \\
\text { barang }\end{array}$ & $\begin{array}{l}\text { Klik pada } \\
\text { menu } \\
\text { barang. }\end{array}$ & $\begin{array}{l}\text { Menampilk } \\
\text { an halaman } \\
\text { supplier } \\
\text { login. }\end{array}$ & $\begin{array}{l}\text { Menampil } \\
\text { kan } \\
\text { halaman } \\
\text { supplier } \\
\text { login. }\end{array}$ & VALID \\
\hline 2. & $\begin{array}{l}\text { Halama } \\
\text { n } \\
\text { Notifik } \\
\text { asi }\end{array}$ & $\begin{array}{l}\text { Pengujian } \\
\text { menampil } \\
\text { kan } \\
\text { halaman } \\
\text { notifikasi }\end{array}$ & $\begin{array}{l}\text { Klik pada } \\
\text { notifikasi }\end{array}$ & $\begin{array}{l}\text { Menampilk } \\
\text { an } \\
\text { informasi } \\
\text { untuk } \\
\text { supplier }\end{array}$ & $\begin{array}{l}\text { Sistem } \\
\text { menam } \\
\text { pilkan } \\
\text { informasi } \\
\text { untuk } \\
\text { supplier }\end{array}$ & VALID \\
\hline 3. & $\begin{array}{l}\text { Halama } \\
\text { n Menu } \\
\text { Transa } \\
\text { ksi dan } \\
\text { Return }\end{array}$ & $\begin{array}{l}\text { Pengujian } \\
\text { menampil } \\
\text { kan } \\
\text { halaman } \\
\text { transaksi } \\
\text { dan return }\end{array}$ & $\begin{array}{l}\text { Klik pada } \\
\text { menu } \\
\text { transaksi } \\
\text { dan return }\end{array}$ & $\begin{array}{l}\text { Menampilk } \\
\text { an halaman } \\
\text { berisi data } \\
\text { transaksi } \\
\text { dan return } \\
\text { supplier }\end{array}$ & \begin{tabular}{|l|} 
Sistem \\
menam \\
pilkan \\
halaman \\
transaksi \\
dan return \\
supplier \\
\end{tabular} & VALID \\
\hline 4 & \begin{tabular}{|l|} 
Halama \\
n Menu \\
Barang \\
Tunda
\end{tabular} & $\begin{array}{l}\text { Pengujian } \\
\text { menampilk } \\
\text { an halaman } \\
\text { barang } \\
\text { tunda }\end{array}$ & $\begin{array}{l}\text { Klik pada } \\
\text { menu } \\
\text { barang } \\
\text { tunda }\end{array}$ & $\begin{array}{l}\text { Menampilk } \\
\text { an } \\
\text { informasi } \\
\text { barang } \\
\text { yang } \\
\text { ditunda }\end{array}$ & \begin{tabular}{|l|} 
Sistem \\
dapat \\
menampilk \\
an \\
informasi \\
barang \\
tunda \\
\end{tabular} & VALID \\
\hline
\end{tabular}

Dari Tabel II, dapat dilihat fitur yang dibuat telah diuji dan didapatkan hasil yang sebenarnya sudah sesuai dengan analisis kebutuhan sistem dan user stories owner. Pengujian ini telah tervalidasi fitur yang diuji sesuai dengan hasil sebenarnya. Fitur-fitur yang diuji diantaranya yaitu fitur menu barang, fitur notifikasi, dan fitur barang tunda . Masing-masing fitur diuji untuk menampilkan halaman saat admin melakukan perintah/ klik pada fitur tersebut. Pengujian juga dilakukan pada tombol aksi disetiap fitur dan hasil yang didapat tombol aksi dapat berjalan sesuai perintah.

\section{Skala Likert}

Pengujian selanjutnya dilakukan dengan menggunakan kuesioner untuk mengetahui penilaian terhadap sistem yang sudah dibuat. Hasil dari kuesioner tersebut, selanjutnya dilakukan perhitungan bobot poin menggunakan Skala Likert. Metode Skala Likert merupakan metode yang digunakan untuk menggukur tingkat kepuasan pengguna menggunakan skala 
pengukuran yang dikembangkan oleh Likert pada Tahun 1932. Skala likert memiliki empat atau lebih butir-butir pertanyaan yang dikombinasikan sehingga membentuk sebuah skor atau nilai yang mempersentasikan sifat individu, misalkan pengetahuan, sikap dan perilaku. Skala likert dapat juga dikatan sebagai skala psikometrik yang umum digunakan dalam kuesioner dan merupakan skala yang paling banyak digunakan untuk penelitian. Biasanya disediakan lima pilihan skala dengan format seperti: Sangat setuju, Setuju, Cukup setuju, Kurang setuju, dan Tidak setuju [18].

Pengujian ini melibatkan 30 orang responden yang dibagi menjadi 2 bagian yaitu pegawai perusahaan dan supplier yang masing-masing berjumlah 15 orang. Pengujian ini dilakukan dengan memerintahkan pegawai dan supplier yang ada di perusahaan tersebut untuk menggunakan sistem yang sudah jadi dan mengisi kuesioner yang terdiri dari 8 butir pernyataan. Setiap pernyataan memiliki 5 penilaian. Pilihan penilaian terdiri dari Sangat Setuju (SS) dengan bobot 5, Setuju (S) dengan bobot 4, Cukup Setuju (CS) dengan bobot 3, Kurang Setuju (KS) dengan bobot 2, dan Tidak Setuju (TS) dengan bobot 1 . Tujuan pembagian tersebut karena adanya perbedaan fitur di sistem pada user admin dan user supplier. Hasil analisis lembar kuesioner penilaian akan menggunakan interprestasi presentase menurut Diani dkk yaitu saat tingkat hasil rata-rata pencapaian $>\quad 80 \%$ memiliki kualifikasi Sangat Baik, $\quad 60 \%<\mathrm{X} \leq 80 \%$ memiliki kualifikasi Baik, $40 \%<\mathrm{X} \leq 60 \%$ memiliki kualifikasi Ragu-Ragu, $20 \%<\mathrm{X} \leq 40 \%$ memiliki kualifikasi Kurang Baik, dan $0 \%<\mathrm{X} \leq 20 \%$ memiliki kualifikasi Tidak Baik [19].

Tabel III merupakan hasil dari penilaian pegawai perusahaan terhadap kuesioner yang terdiri dari 8 butir pernyataan dengan 5 kategori penilaian. Hasil presentase yang didapatkan setelah dihitung rata-rata dengan skala likert yaitu $79,83 \%$ yang artinya pegawai di perusahaan tersebut menilai sistem pendataan barang dan supplier ini sudah baik.

TABEL III

Hasil Penilaian Responden Pegawai Terhadap Kuesioner

\begin{tabular}{|c|l|c|c|}
\hline No & \multicolumn{1}{|c|}{ Pernyataan } & Total & $\begin{array}{l}\text { Index } \\
\%\end{array}$ \\
\hline 1 & $\begin{array}{l}\text { Sistem dapat menyajikan informasi yang } \\
\text { jelas dan mudah dimengerti }\end{array}$ & 59 & $78,67 \%$ \\
\hline 2 & $\begin{array}{l}\text { Tata letak/ komposisi/ fitur pada sistem } \\
\text { mudah untuk dipahami dan digunakan } \\
\text { (easy to use) }\end{array}$ & 61 & $81,33 \%$ \\
\hline 3 & $\begin{array}{l}\text { Tombol yang ada pada sistem dapat } \\
\text { berfungsi dengan baik }\end{array}$ & 63 & $84,00 \%$ \\
\hline 4 & $\begin{array}{l}\text { Sistem dapat memunculkan pesan } \\
\text { konfirmasi saat data akan dihapus atau }\end{array}$ & 59 & $78,67 \%$ \\
\hline
\end{tabular}

\begin{tabular}{|c|l|c|c|}
\hline & jika terjadi error & & \\
\hline 5 & $\begin{array}{l}\text { Sistem dapat menyimpan data yang telah } \\
\text { diinputkan dan proses input data yang } \\
\text { mudah digunakan }\end{array}$ & 56 & $74,67 \%$ \\
\hline 6 & $\begin{array}{l}\text { Sistem mudah untuk diaccess (tidak } \\
\text { terjadi crash/not responding) }\end{array}$ & 56 & $74,67 \%$ \\
\hline 7 & $\begin{array}{l}\text { Penilaian anda terhadap sistem dapat } \\
\text { membantu anda mempercepat mendata } \\
\text { supplier, barang, dan pembelian }\end{array}$ & 66 & $88,00 \%$ \\
\hline 8 & $\begin{array}{l}\text { Penilaian anda terhadap sistem dapat } \\
\text { membantu anda dalam pengambilan } \\
\text { keputusan }\end{array}$ & 59 & $78,67 \%$ \\
\hline \multicolumn{2}{|c|}{ Total Rata-Rata (\%) } \\
\hline
\end{tabular}

Tabel IV merupakan hasil dari penilaian supplier yang bekerja sama dengan perusahaan terhadap kuesioner yang terdiri dari 8 butir pernyataan dengan 5 kategori penilaian. Hasil presentase yang didapatkan setelah dihitung rata-rata dengan skala Likert yaitu $77,17 \%$ yang artinya pegawai perusahaan tersebut menilai sistem pendataan barang dan supplier ini sudah baik.

TABEL IV

Hasil PENILAIAN RESPONDEN SUPPLIER TERHADAP KUESIONER

\begin{tabular}{|c|l|c|c|}
\hline No & \multicolumn{1}{|c|}{ Pernyataan } & Total & $\begin{array}{c}\text { Index } \\
\text { \% }\end{array}$ \\
\hline 1 & $\begin{array}{l}\text { Sistem dapat menyajikan informasi } \\
\text { yang jelas dan mudah dimengerti }\end{array}$ & 59 & $78,67 \%$ \\
\hline 2 & $\begin{array}{l}\text { Fitur notifikasi pada sistem dapat } \\
\text { menyediakan informasi terbaru (up } \\
\text { to date) secara real time }\end{array}$ & 58 & $77,33 \%$ \\
\hline 3 & $\begin{array}{l}\text { Sistem (tata letak/ komposisi/ fitur) } \\
\text { mudah untuk dipahami dan } \\
\text { digunakan (easy to use) }\end{array}$ & 55 & $73,33 \%$ \\
\hline 4 & $\begin{array}{l}\text { Tombol yang ada pada sistem dapat } \\
\text { berfungsi dengan baik }\end{array}$ & 61 & $81,33 \%$ \\
\hline 5 & $\begin{array}{l}\text { Sistem dapat memunculkan pesan } \\
\text { konfirmasi saat terjadi } \text { error }\end{array}$ & 57 & $76,00 \%$ \\
\hline 6 & $\begin{array}{l}\text { Sistem mudah untuk diaccess (tidak } \\
\text { terjadi crash/not responding) }\end{array}$ & 59 & $78,67 \%$ \\
\hline 7 & $\begin{array}{l}\text { Penilaian anda terhadap sistem, } \\
\text { memudahkan anda melakukan } \\
\text { pengiriman barang ke perusahaan } \\
\text { karena fitur barang tunda }\end{array}$ & 61 & $81,33 \%$ \\
\hline 8 & $\begin{array}{l}\text { Penilaian anda terhadap sistem } \\
\text { dapat membantu anda dalam } \\
\text { mengetahui sisa stok barang yang } \\
\text { ada di perusahaan lewat fitur } \\
\text { notifikasi }\end{array}$ & 53 & $70,67 \%$ \\
\hline & \multicolumn{1}{|c|}{ Total Rata-Rata (\%) } \\
\hline
\end{tabular}

\section{KESIMPULAN}

Adapun kesimpulan yang didapat dari hasil penelitian ini yaitu menghasilkan sebuah sistem informasi untuk 
pendataan supplier dan barang di salah satu perusahaan yang ada di Bandar Lampung berbasis web dengan menggunakan framework Laravel. Sistem berhasil melakukan pendataan supplier, barang, transaksi pengiriman, return barang, dan juga dapat memberikan notifikasi kepada supplier. Pendataan barang termasuk didalamnya yaitu kode barang, satuan barang, posisi rak barang, dan kategori barang.

Metode yang digunakan dalam membangun sistem informasi ini menggunakan metode Extreme Programming (XP) yang mana memiliki empat tahap yaitu planning, design, coding, dan testing. Pengujian yang dilakukan dalam penelitian ini menggunakan Black Box Testing untuk menguji fungsionalitas sistem. Hasil dari pengujian tersebut sistem dapat berfungsi dengan baik sesuai request dan tidak terdapat error.

Hasil kuesioner yang dilakukan pada penelitian ini yaitu, pada bagian pegawai perusahaan sebanyak 15 responden dengan masing-masing menjawab 8 butir penyataan menghasilkan presentase rata-rata nilai yang dihitung dengan skala Likert yaitu $79,83 \%$ yang artinya pegawai perusahaan tersebut menilai sistem yang dibuat sudah baik. Sedangkan, pada bagian supplier yang bekerja sama dengan perusahaan diambil sebanyak 15 responden dengan masingmasing menjawab 8 butir penyataan menghasilkan presentase rata-rata nilai yang dihitung dengan skala Likert yaitu $77,17 \%$ yang artinya supplier di perusahaan tersebut menilai sistem yang dibuat sudah baik.

Berdasarkan hasil dari penelitian ini, terdapat beberapa saran untuk pengembangan selanjutnya yaitu menambahkan fitur life chat antara owner dan supplier agar lebih mudah berdiskusi saat melakukan restock barang dan menambahkan fitur laporan untuk data supplier, data barang, dan data transaksi pembelian barang.

\section{DAFTAR PUSTAKA}

[1] S. Kodu, "Harga, kualitas produk, dan kualitas pelayanan pengaruhnya terhadap keputusan pembelian mobil toyota avanza," Jurnal Riset Ekonomi, Manajemen, Bisnis dan Akuntansi, vol. 1, pp. 1252-1259, September 2013.

[2] C. Schuh, M. F. Strohmer, S. Easton, M. D. Hales, \& A. Triplat, Supplier elationship Management: How to Maximize Vendor Value and Opportunity, New York City: Apress 2014.

[3] M. Soediro, "Analisis pengaruh top management commmitment terhadap supplier performance dan supplier relationship management pada hotel Budget di Surabaya," Jurnal Ilmiah Manajemen dan Akuntansi, vol. 4, pp. 1-12, Juni 2017.
[4] H. Agusvianto, "Sistem informasi inventori gudang untuk mengontrol persediaan barang pada gudang studi kasus : PT. Alaisys Sidoarjo," Journal Information Engineering and Educational Technology, vol. 1, pp. 40-46, Agustus 2017.

[5] P. H. Sutanto, "Perancangan sistem stok barang di warehouse berbasis web," Jurnal Sistem Komputer Musirawas, vol. 4, pp. 9-18, Juni 2019.

[6] R. Mantala, "Perancangan dan implementasi sistem informasi persediaan bahan baku dan suku cadang di PT. Triteguh Manunggal Sejati Banjarbaru," Jurnal POSITIF, vol. 2, pp. 16-20, November 2016.

[7] B. Nugroho, Program Toko dengan Visual Basic dan MySQL. Yogyakarta, Indonesia: Gava Media 2014

[8] J. O'Brien, Supplier Relationship Management: Unlocking the Hidden Value in Your Supply Base. London: Kogan Page 2014.

[9] Deloitte AG, "Supplier Relationship Management (SRM): Identifying and maximising the value of strategic supplier partnering". London: The Creative Studio at Deloitte, 2015.

[10] R. V. Hoek, Supplier Relationship Management "How Key Suppliers Drive Your Company's Competitive Advantage”. Netherlands: Pricewaterhouse Coopers Accountants, 2013.

[11] U. Pauziah, "Perancangan sistem pendataan penduduk pada kelurahan Cililitan Jakarta Timur berbasis delphi," Faktor Exacta, vol. 6, pp. 189-199, Maret 2013.

[12] Y. I. Chandra, "Perancangan aplikasi resep masakan tradisional indonesia menggunakan pendekatan agile process dengan model extreme programming berbasis android," Proceeding Seminar Nasional APTIKOM, 2016, vol. 1, pp.607-614.

[13] R. V. Anand \& M. Dinakaran, "Popular agile methods in software development: review and analysis," Int. J. Appl. Eng. Res. ISSN, vol. 11, no. 5, pp. 973-4562, 2016.

[14] A. Fatoni \& D. Dwi, "Rancang bangun sistem extreme programming sebagai metodologi pengembangan sistem," Jurnal PROSISKO, vol. 3, pp.17-20, Maret 2016.

[15] M. A. Prayoga, Y. S. Siregar, S. Khairani, "Perancangan aplikasi pemilihan ketua organisasi di fakultas teknik dan komputer Universitas Harapan Medan menggunakan metode extreme programming berbasis android," Proceeding SNASTIKOM, 2019, pp.211-218.

[16] I.G.N.Suryantara, Merancang Aplikasi dengan Metodologi Extreme Programmings.Jakarta, Indonesia: PT Elex Media Komputindo, 2017.

[17] T. Hidayat \& M. Muttaqin, "Pengujian sistem informasi pendaftaran dan pembayaran wisuda online menggunakan black box testing dengan metode equivalence partitioning dan boundary value analysis," Jurnal Teknik Informatika UNIS, vol. 6, pp.25-29, Oktober 2018.

[18] S.Syofian, T. Setyaningsih, N. Syamsiah, "Otomatisasi metode penelitian skala likert berbasis web," Proceeding Seminar Nasional Sains dan Teknologi, 2015, vol. 2, pp.1-8.

[19] R. Diani, Yuberti, \& S. Syafitri, "Uji effect size model pembelajaran scramble dengan media video terhadap hasil belajar fisika peserta didik kelas x MAN 1 Pesisir Barat," Jurnal Ilmiah Pendidikan Fisika Al-BiRuNi, vol. 5, pp.265-275, 2016. 